\title{
Bahasa dan Konsep Agama: Studi Alih Kode dalam Ceramah Agama K.H Jamaludin
}

\author{
Moch Habibi ${ }^{1}$
}

\section{Abstract}

This study aims to find out the code switching from Sundanese to Arabic, the number of switch words that occur in the Arabic language absorption element and find out the factors that lead to the code switching from Sundanese to Arabic and vice versa in Sundanese religious speech of KH Jamaludin Pandeglang-Banten. This research uses the theory of code switching. This research was conducted by analyzing the transition of language in text of Sundanese religious speech of K.H Jamaludin. Data analysis method used in this research is the method of code switching analysis. Using the method of code switching, the analysis will focus on the linguistic and contextual aspects associated with those aspects. Data in the text will be analyzed by using analysis of code switching model that Appel expressed the transition phenomenon of language usage due to situation change. The results of this study show the code switching from Sundanese to Arabic. There are many of code switching from Sundanese to Arabic in the religious speech of KH Jamaludin in front of his congregation. Though the congregation who attended were not all citizens of the Sundanese community. There are also people speak Serang and Lampung's Javanese. But with a culture approach put forward by K.H Jamaludin, finally the concepts of understanding and reality of language diversity in his speech will be easily understood. The discourse of speech interaction of KH Jamaludin in Banten or outside Banten, it is an important event for Muslims who listen to the speech delivered by KH Jamaludin that shows the Indonesian-Sundanese-Arabic code switching. It is based on the observation and analysis of the data, the variation of language and the type of language used through the recorded video transcripted. There are several factors causing the code switching: 1) situation factor, 2) psychological factor, 3) language and Islamic politics.

Keywords: Sundanese-Arabic Code Switching, Religious Speech of K.H Jamaludin Pandeglang, Banten

\section{Abstrak}

Penelitian ini bertujuan untuk mengetahui kata pinjaman dari bahasa Arab ke bahasa Sunda, perubahan makna yang terjadi pada unsur bahasa serapan bahasa Arab menemukan faktor-faktor yang menyebabkan terjadinya alih kode dari bahasa Sunda ke bahasa Arab dan sebaliknya. pada ceramah keagamaan K.H Jamaludin Pandeglang-Banten, penelitian ini menggunakan teori Sosilinguistik Alih Kode, metode analisis data yang digunakan dalam penelitian ini adalah analisis alih kode, difokuskan pada aspek kebahasaan yang terkait dengan aspek sosiolinguistik. Data yang berupa teks dianalisis dengan menggunakan model alih kode yang diungkapkan Appel yaitu gejala peralihan bahasa karena berubahnya situasi. Alih kode dari bahasa Sunda ke bahasa Arab cukup banyak dilakukan oleh penceramah saat memberikan materi ceramah atau khutbah di hadapan para jamaahnya. Padahal jamaah yang hadir di acara tersebut tidak semuanya warga masyarakat Sunda namun ada juga warga masyarakat berbahasa Jawa Serang dan Lampung. Namun dengan pendekatan kultur yang lebih dikedepankan oleh K.H Jamaludin, akhirnya pemahaman dan realiatas keberagaman bahasa dalam ceramahnya akan mudah ditoleril. Dari pengamatan data, variasi bahasa dan tipe penggunaan bahasa yang diperoleh melaui rekaman video yang dijadikan ke dalam teks dapat ditemukan faktor-faktor penyebab Alih Kode, yaitu berikut : 1) faktor situasi, 2) faktor kejiwaan, 3) politik bahasa dan politik islam.

Kata Kunci: Bahasa dan Konsep Agama Studi Alih Kode dalam Ceramah Agama K.H Jamaludin

\footnotetext{
${ }^{1}$ Program Studi Bahasa dan Sastra Arab, Fakultas Adab dan Humaniora, UIN Syarif Hidayatullah Jakarta, 2018
} 


\section{A. Pendahuluan}

Bahasa mempunyai fungsi yang sangat penting bagi manusia, terutama fungsi komunikasi. Bahasa merupakan alat interaksi sosial atau alat komunikasi manusia. Dalam setiap kegiatan, bahasa dapat memberikan informasi yang berupa pikiran, gagasan, maksud, perasaan maupun secara langsung. Komunikasi adalah penyampaian pesan dan maksud dari seseorang kepada orang lain melalui bahasa. sehingga terjadinya keragaman bahasa ini bukan hanya penuturnya yang tidak homogen, tetapi juga karena kegiatan interaksi sosial yang dilakukan sangat beragam. Setiap kegiatan memerlukan terjadinya keragaman bahasa itu. ${ }^{2}$

Appel mendefinisikan alih kode itu sebagai "gejala peralihan pemakaian bahasa karena berubahnya situasi" dalam penggunaanya bisa kita terapkan dalam kehidupan sehari-hari pada masyarakat. ${ }^{3}$ Masyarakat yang multi bahasa muncul karena masyarakat tersebut menguasai lebih dari satu bahasa sehingga dapat menggunakan bahasa dalam kegiatan komunikasi apapun contohnya dalam berceramah agama, seminar atau dalam kegiatan sosial lainnya. Menurut Ohoitun (2003) alih kode dan campur kode yaitu beralihnya bahasa atau dialek kedalam bahasa atau dialek lainya, ini harus berlangsung secara konsisten karena ini akan menerangkan tentang identitas penutur, pengaruhnya dan apa maksud dari pemanfaatan dari peralihan bahasa tersebut. ${ }^{4}$

Salah satu kiaidiwilayahBantentepatnya salah satu kabupaten yang dikenal sebagai kota seribu ulama dan sejuta

${ }^{2}$ (Abdul Chair \& Leonie Agustina, 2010)

${ }^{3}$ (Abdul Chair \& Leonie Agustina, 2010)

${ }^{4}$ (Abdul Chair \& Leonie Agustina, 2010) santri yakni Kabupaten Pandeglang. Ada seorang ulama yang cukup dikenal para masyarakat dari elementasi manapun, Yaitu K.H Jamaludin beliau adalah salah satu tokoh ulama yang ada di Kabupaten Pandeglang. K. H Jamaludin menggunakan bahasa Sunda dalam berkomunikasi pada ceramahnya dan para jamaahnya bukan hanya dari Sunda saja, K.H Jamaludin mencoba menerapkan dalam ceramahnya komunikasi antar budaya dengan mempertimbangkan tempat, jarak fisik dengan para jamaah dan pembicaraan atau materi dalam ceramahnya ${ }^{5}$ dan K.H Jamaludin cukup dikenal dengan ceramah agama yang menggunakan bahasa Sunda yang sangat identik dengan ketegasan, lugas dan keras.

Salah satu unsur ketua MUI Kabupaten Pandeglang yaitu K.H Uwet Dimyathy S.Ag beliau menerangkan tentang beberapa ulama yang sering menggunakan bahasa Sunda dalam berkomunikasi pada kegiatan-kegiatan agama namun kurang konsisten dalam mempertahankan identitas pribadinya sebagai orang Sunda. Beliaupun mengakui bahwasanya ada seorang ulama yang konsisten dalam berceramah agama menggunakan bahasa Sunda yaitu K.H Jamaludin.

Menurut K.H Uwet, Ki Jamaludin adalah seorang penceramah agama yang sangat konsisiten mempertahankan bahasa daerahnya namun terkadang ada keterpengaruhan bahasa asing di luar bahasa Indonesia, yaitu bahasa Arab. Hal ini sangat menarik karena Ki Jamaludin selalu menggunakan bahasa Sunda dengan dipengaruhi bahasa Arab sebagai peralihan bahasa beliau dari bahasa Sunda ke bahasa Arab dalam ceramahnya walaupun itu di daerah di ${ }^{5}$ (Deddy Mulyana \& Jalaluddin Rakhmat, 2006) 
luar wilayah Sunda. Gejala ini biasa terjadi ketika para penutur dalam bahasa tersebut masih hidup. ${ }^{6}$

Ki Jamaludin sangat dikenal dengan bahasa yang keras dan ceramah-ceramah yang sangat menggetarkan hati, beliau sering memasukan permainan bahasa dan anekdot-anekdot sehingga banyak istilah-istilah Sunda yang terkadang kurang difahami oleh para pendengar ceramahnya, namun ini menarik menurut saya karena diceramah beliau, beliau sangat bersikeras berceramah menggunakan bahasa Sunda walaupun di wilayah luar Banten. Dalam hal ini menunjukan bahwa prilaku tutur atau tindak tutur (speech act) sebagai satu rangkaian hubungan antara dua orang atau lebih. ${ }^{7}$

Berdasarkan latar belakang diatas, masalah yang diangkat penulis dalam penelitian ini adalah bagaimana bentuk Alih Kode bahasa Arab yang dituturkan oleh K.H Jamaludin dalam ceramah keagamaan, Faktor-faktor yang menyebabkan terjadinya Alih Kode, fungsi alih kode dalam ceramah keagamaan dan bagaimana bentuk kata pinjaman dalam bahasa Arab yang dituturkan oleh K.H Jamaludin Pandeglang dalam ceramah keagamaan bahasa Sunda Pandeglang.

Penelitian ini bertujuan memperoleh deskripsi dan pemahaman mengenai bentuk Alih Kode bahasa Arab yang dituturkan oleh K.H Jamaludin dalam ceramah keagamaan, menemukan faktor-faktor yang menyebabkan terjadinya alih kode oleh penceramah, mengetahui fungsi alih kode dan bentuk kata pinjaman dalam bahasa Arab yang dituturkan oleh K.H Jamaludim ${ }^{6}$ (Sudarno, 1992)

${ }^{7}$ (Abdul Chair, 2002)
Pendeglang dalam ceramah keagamaan bahasa Sunda Pandeglang.

Hasil penelitian ini diharapkan dapat menambah pengetahuan dan pemahaman bagi pihak-pihak terkait tentang kajian sosiolinguistik dalam menganalisis perubahan bahasa dan pengalihan kode dalam berbagai situasi dalam berceramah, pengaruh perbedaan bahasa khususnya pada penggunaan Bahasa Sunda, dan pengaruh bahasa asing (Bahasa Arab). Manfaat lainnya adalah sebagai sumbangan dalam memperkaya pengetahuan tentang bahasa, Alih Kode dan pengembangan bahasa yang hidup pada masyarakat Indonesia masa kini, pada ceramah Ulama di Pandeglang khususnya K.H Jamaludin.

Dalam penelitian ini, penulis menggunakan metode kualitatif. metode penelitian kualitatif merupakan prosedur penelitian yang menghasikan data deskriptif berupa kata-kata tertulis ataupun lisan dari orang-orang dan perilaku yang diamati. ${ }^{8}$

Dalam suatu penelitian, penentuan metode dan teknik pengumpulan data merupakan suatu langkah penting yang harus dilakukan agar data yang diperoleh akan lebih akurat, lengkap, dan representatif. Dalam penelitian ini, peneliti meggunakan beberapa metode pengumpulan data, salah satunya adalah metode simak. Metode simak dilakukan untuk menyimak penggunaan bahasa. Istilah menyimak disini juga tidak berkaitan dengan penggunaan bahasa secara lisan, tetapi juga penggunaan secara tertulis. ${ }^{9}$

Dalam penelitian ini peneliti menyimak

${ }^{8}$ (Muhammad, 2011)

${ }^{9}$ (M.S, Mahsun, 2012) 
beberapa ceramaah kegamaan yang didapat dari media sosial yaitu Youtube, dalam ceramah keagamaanya K.H Jamaludin variatif dalam membawakan tema dan dibumbui dengan anekdotanekdot yang mengundang gelak tawa dan juga beliau selalu konsisten dalam membawakan ceramahnya menggunakan bahasa Sunda dan beralih ke bahasa Arab, peneliti akan menganalisis dalam perpidahan bahasa dan perubahan bahasa dalam ceramah beliau dari unsur alih kode, campur kode dan perubahan bahasa.

Metode simak ini memiliki teknik dasar yang berupa teknik sadap. Maksud teknik sadap disini adalah menyadap penggunaan bahasa, baik penggunaan bahasa secara lisan maupun tulisan lisan. Dalam praktiknya, teknik sadap ini diikuti dengan teknik lanjutan yaitu teknik simak libat cakap, teknik simak bebas libat cakap, teknik catat dan teknik rekam. ${ }^{10}$ Metode simak dalam penelitian ini meggunakan teknik lanjutan berupa teknik simak bebas libas cakap, peneliti menyadap prilaku berbahasa dalam suatu pristiwa tutur dengan tanpa terlibat dalam peristiwa tersebut. Jadi, peneliti hanya berperan sebagai pengamat. Penulis hanya mengamati penggunaan bahasa dalam teks pada ceramah keagamaan K.H Jamaludin Pandeglang-Banten tanpa terlibat dalam peristiwa tutur tersebut, karena memang objek penelitianya berbentuk Audio Visual yang dibentuk kedalam teks tertulis.

Teknik lain yang digunakan dalam tahap pengumpulan data ini adalah teknik catat. Teknik catat dalam penelitian ini digunakan untuk mencatat elemenelemen yang menjadi bagian dari struktur seperti perbedaan bahasa, ${ }^{10}$ (M.S, Mahsun, 2012) imbuhan, sisipan, alih kode dan campur kode. Setiap elemen tersebut dapat menunjukan peralihan bahasa yang digunakan oleh K.H Jamaludin Pandeglang serta penguasaan bahasa apa saja yang dikuasai oleh beliau.

Selain metode simak, metode pengumpulan data yang juga digunakan dalam penelitian ini adalah metode studi pustaka. Metode studi pustaka ini dilakukan dengan menghimpun buku-buku, jurnal dan karya ilmiah lainya yang berkaitan dengan masalah penelitian. Data yang relevan dengan masalah penelitian akan dicatat dan digunakan sebagai data pendukung dalam penelitian. Metode dan teknik pengumpulan data yang digunakan dalam penelitian ini digambarkan sebagai berikut :

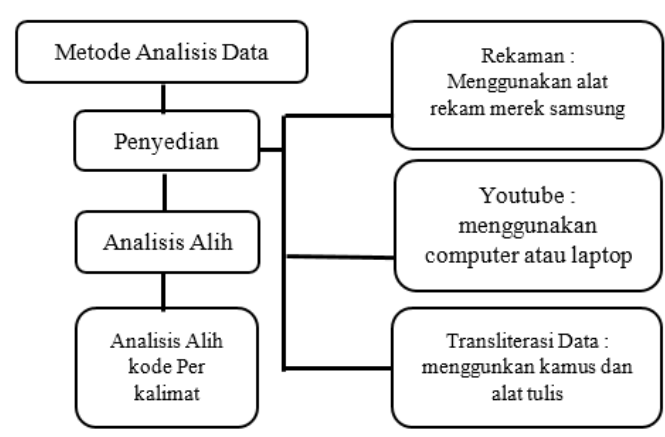

Sumber : Diilustrasikan dari (M.S, Mahsun, 2007) dengan penambahan dan modifikasi dari peneliti

Sedangkan, metode analisis data yang digunakan dalam penelitian ini adalah metode analisis Alih Kode. Dengan menggunakan metode analisis alih kode, analisis akan difokuskan pada aspek kebahasaan dan konteks yang terkait dengan aspek-aspek tersebut.

Peneliti akan menggunakan analisis alih kode dalam penelitian ini dan akan mengetahui penguasaan bahasa yang 
dimiliki oleh K.H Jamaludin dengan cara menghubungkan unsur-unsur yang terdapat dalam suatu bahasa ataupun beberapa bahasa yang berbeda. ${ }^{11}$

Menurut Ohoitun alih kode dan campur kode yaitu beralihnya bahasa atau dialek kedalam bahasa atau dialek lainya, ini harus berlangsung secara konsisten karena ini akan menerangkan tentang identitas penutur, pengaruhnya dan apa maksud dari pemanfaatan dari peralihan bahasa tersebut. ${ }^{12}$ Peneliti akan menggambarkan klasifikasi alih kode serta peralihan bahasa yang dilakukan oleh K.H Jamaludin sebagai berikut :

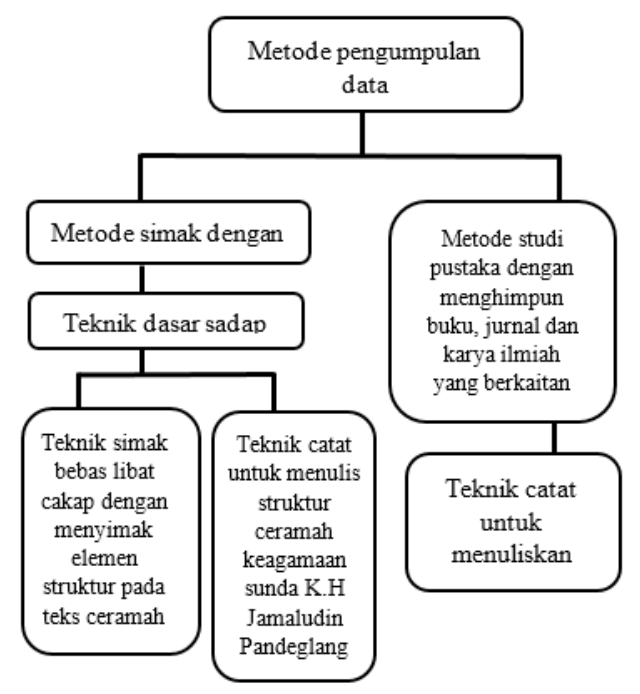

Sumber : Diilustrasikan dari (M.S, Mahsun, 2007) dengan penambahan dan modifikasi dari peneliti.

\section{B. Pembahasan}

Uraian pembahasan ini dimaksudkan untuk mengungkapkan kembali temuan-temuan hasil penelitian, dilihat dari segi teori yang menjadi landasanya dan hasil-hasil penelitian yang relevan sebelumnya. Pembahasan ini akan dipaparkan menurut urutan

11 (M.S, Mahsun, 2007)

12(Abdul Chair \& Leonie Agustina, 2010) permasalahan, dan uraian pembahasan ini akan memperlihatkan tujuan dan pengaruh bahasa Arab dalam bahasa Sunda yang terdapat dalam ceramah keagamaan bahasa Sunda K.H Jamaludin Pandeglang-Banten selanjutnya disingkat (CKBS K.H Jamaludin).

\section{Variasi Bahasa CKBS K.H Jamaludin}

Dalam penelitian ini peneliti melihat dari dasar bahasa, perisitiwa alih kode dikategorikan dalam tiga variasi bentuk, yaitu : (1) alih kode dengan kode dasar kode bahasa Sunda (BS) $\rightarrow$ (BA), (2) alih kode dengan kode dasar bahasa Arab $(\mathrm{BA}) \rightarrow(\mathrm{BS})$, (3) alih kode dengan kode dasar bahasa Indonesia $(\mathrm{BI}) \rightarrow(\mathrm{BS})$ $\rightarrow$ (BA). Meskipun demikian CKBS K.H Jamaludin sering melakukan alih kode, namun intensitas BS masih tetap sering dipergunakan dalam komunikasi pada ceramah keagamaan bahasa Sunda yang dilakukan oleh K.H Jamaludin.

Alih kode yang terjadi pada CKBS K.H Jamaludin dapat dilihat pada data no 1.1 dan no 2.1 dalam ceramah Sunda K.H Jamaludin, penceramah atau penutur melakukan alih kode karea berubahnya situasi dan sebagai identitas sosial, dalam ceramah keagamaan berbahsa Sunda (BS), penutur lebih intens menggunakan bahasa Sunda yang dimana pada situasi penutur ingin memberikan gambaran tentang identitas penutur yang berasal dari suku Sunda, dengan melakukan dakwah dalam hal ini adalah ceramah keagamaan yang beliau lakukan, sering teradi atau dilaksanakan di wilayah Banten yang notabene tidak seluruhya menggunakan bahasa Sunda ada yang menggunakan bahasa Jawa Serang, ada yang menggunakan Sunda lampung atau bahasa Indonesia.

Secara sosial perubahan penggunaan 
bahasa itu memang harus dilakukan, sebab sangatlah tidak bisa difahami oleh para pedengar, yaitu para jamaah yang menggunakan multi bahasa, namun dibenarkan di Banten mayoritas adalah bahasa Sunda, karena objek dalam penelitian ini adalah ceramaah keagamaan pasti banyak kata-kata tentang peguatan atau refresial dari bahasa asing lainya, yaitu bahasa Arab. Oleh karea itu alih kode dapat dikatakan mempunyai fungsi sosial gejala alih kode $\mathrm{BS} \rightarrow$ BA $\rightarrow$ BI dalam ceramah keagaamaan bahasa Sunda K.H Jamaludin sebagai peralihan bahasa.

Menurut Abdul Chaer dan Leonie (2010) peristiwa pergantian bahasa, atau berubahya dari ragam santai ke ragam resmi, atau juga ragam resmi ke ragam santai, inilah yang disebut peristiwa alih kode dalam sosiolinguistik. misalnya dari bahasa Sunda ke bahasa Indonesia atau bahasa Indonesia ke bahasa Sunda. Alih kode ekstern terjadi bahasanya sendiri dengan bahasa asing. Karena penutur sering menggunakan bahasa Arab dalam peguatan dalil-dalil keagamaan yang disampaikan dalam ceramah keagamaan bahasa Sunda tersebut, sebagai suatu penjelasan terhadap sebuah hukum yang penutur sampaikan dalam isi ceramah tersebut, karena dalam lingkungan pendengar atau biasa disebut jamaah terdapat latar belakang suku yang variatif, diantaranya suku Sunda, suku Jawa dan Lampung. Penutur ingin memberikan rasa kesamaan terhadap jamaah dalam konsepsi bahasa yang beliau utarakan.

\section{Penggunaan Bahasa}

Penggunaan bahasa menggunakan ranah konsep suatu variasi bahasa cederung lebih tepat digunakan pada variasi lain, maka ranah difahami sebagai konstelasi faktor-faktor seperti lokasi, topik dan partisipasi. Berdasarkan hasil analisis dalam ceramah keagamaan bahasa Sunda K.H Jamaludin Pandeglang membentuk pengguaan bahasa yang teratur dan tidak acak, keteraturan tersebut tergambar dengan keteraturan peggunaan bahasa tersebut, papara tipetipe itu sebagai berikut :

\section{a). Tipe Peggunaan bahasa dalam CKBS} K.H Jamaludin dan faktor social

Melihat dari hasil penelitian dan rekaman yang dilakukan terdapat tiga tipe yaitu (1) BS, (2) $\mathrm{BA}+\mathrm{BS}$ (3) $\mathrm{BA}+\mathrm{BS}+\mathrm{BI}$. Ketiga tipe tersebut berbeda dengan temuan penelitian Darsita (2012) di Ranau sumatera selatan yaitu : (1) BR, (2) BR+BMP, (3) $\mathrm{BR}+\mathrm{BO}$, (4) $\mathrm{BR}+\mathrm{BJ}+\mathrm{BMP}+\mathrm{BO}+\mathrm{BI}$, (5) $\mathrm{BR}+\mathrm{BI}$ yang menemukan 5 tipe peggunaan bahasa di kalangan masyarakat Ranau. Dalam situasi peggunaan bahasa terdapat fungsi bahasa dan fungsi sosial. Dalam masyarakat yang memiliki dwibahasa atau aneka bahasa pemilihan dan penggunaan bahasa ditentukan oleh beberapa faktor. Ditinjau dari dimensi sosial -psikologis pengguaan dan pemilihan bahasa siapa berbicara bahasa apa, kepada siapa, tentang apa dan dimana. Tentang ranah bahasa oleh seorang penutur mengacu keapada konsep yang dikembangkan oleh Fishman (1965). Siapa berbicara kepada siapa ditentukan lagi oleh faktorfaktor sosial (nonlinguistics), seperti usia penutur-mitra tutur, status sosial, keakraban, kekerabatan, jenis kelamin kemudian dari segi kedudukan dan fungsi bahasa dalam masyarakat, pilihan bahasa dan pemakaian pada hakekatnya terkait dengan status bahasa dalam masyarakat yang merujuk pada konsep (Ferguson, 1959). 
Pemakaian yang digunakan oleh K.H Jamaludin dalam ceramah keagamaan berbahasa Sunda sangat mengacu kepada konsep bahasa yang tergambarkan di atas. Ranah-ranah pemakaian tampak berlangsung seperti apa adanya, situasi kebahasan yang berjalan sebagai fungsi-fungsi itu berpengaruh terhadap alih kode yang dilakukan oleh K.H Jamaludin BA sebagai bahasa Arab yang berasal dari luar atau asing atas bahasa Sunda sebagai bahasa kelompok atau mayoritas di Pandeglang. ${ }^{13}$

K.H Jamaludin sebagai penceramah sebagian besar melakukan pola interaksi verbal dengan para jamaahnya, ini dapat kita lihat pada data no 1.1 pada tabel yang pertama yaitu kata /hadir/ $\{$ \{رض merupakan kosa kata Arab yang diserap ke dalam Bahasa Sunda. Kosa kata ini digunakan dan beradaptasi dengan sistem imbuhan berupa konfiks Bahasa Sunda $\{$ nga- $\}+\{-a n\}$ yang bermakna menunjukan kata kerja. Disini penceramah memperlihatkan adanya penggunaan bahasa dalam ceramahya dalam kata tersebut tersirat imbuhan konfiks adanya imbuhan $\{$ nga- $\}+\{-$ an\} yang fungsi dan kegunaan tersebut adalah menunjukan sebuah perbuatan. Kata ini diambil dari kalimat "/bah urang kaditu dei $(\mathrm{BS}) \rightarrow$ ngahadiran (BA) $\rightarrow$ Kiyai Asep Mubarok ongkoh dei ngulemna geh ka kyai Zaenal waktos aya abdi (BS)/" apabila diterjemahkan kedalam bahasa Indonesia adalah : "Bah saya kesana menghadiri Kiyai Asep Mubarok mengundang juga ke Kiyai Zaenal ketika ada saya". Kalaimat tersebut dituturkan pada ceramah yang diarahkan kepada salah satu jamaah yang dianggap oleh penceramah sudah tua yang menunjukan situasi penggunaan bahasa yang diggunakan harus halus, sopan dan memiliki fungsi sosial. Data ${ }^{13}$ (Wafi, Ali Abdul Wahid, 1971) tersebut menunjukan fungsi bahasa gambaran bahasa digunakan memiliki prilaku bahasa diatas menunjukan penghargaan sosial kepada individu.

Pada data no 4.1 menampakan peralihan kode dari bahasa Arab ke bahasa sunda. Awalnya, K.H Jamaludin menggunakan tuturan bahasa Arab saat menyampaikan materi ceramahnya, tetapi kemudian beralih ke Bahasa Sunda terutama ketika menyampaikan sebuah konsep penting yang perlu diketahui para jamaahnya, dalam hal ini adalah kata "diqudratkeun" dan "diirodatkeun" Ini dilakukan karena penceramah ingin mengungkapan tentang suatu sebab dalam suatu perbuatan yang beliau lakukan, penceramah beralih kode dari bahasa Arab ke bahasa Sunda kemudian berbahasa Arab kembali dan ditambah dengan imbuhan konfiks ini dilakukan karena ingin memberikan penegasan kepada jamaah agar meyakini tentang takdir Allah yang telah diberikan kepada penceramah dalam konteks ini adalah takdir baik dan buruk yang telah diberikan kepada penceramah. Ini adalah pesan agama yang ingin beliau jelaskan kepada jamaah agar yakin kita hidup di dunia ini atas dasar gerakan Allah. Dalam penggalan kalimatnya adalah "Alhamdulillah dikudrotkeun $(B A) \rightarrow$ jeng $(B S) \rightarrow$ diirodatkeun $(B A) \rightarrow k u(B S) \rightarrow$ Allah $(B A) \rightarrow$ sahingga cariosan $(B S) \rightarrow$ almarhum $(B A) \rightarrow$ tercapai (BI)/". Dalam bahasa Indonesia berarti Alhamdulillah semoga ditaqdirkan baik ataupun buruknya oleh Allah sehingga harapan dari pembicaraan dengan almarhum dapat tercapai. Kalimat diatas adanya konfiks $\{$ di- $\}+\{$-eun $\}$ penggunaan imbuhan ini memberikan makna sebuah perbuatan dan fungsinya adalah mempertegas suatu tuturan penceramah dalam menjelaskan isi ceramah tersebut, kalimat penggalan 
diatas meunjukan pealihan bahasa yang berjumlah delapan kali alih kode yang dilakukan dan menggunakan tiga bahasa diawali bahasa Arab (BA) $\rightarrow$ bahasa Sunda (BS) $\rightarrow$ bahasa Arab (BA) $\rightarrow$ bahasa Sunda (BS) $\rightarrow$ bahasa Arab (BA) bahasa Sunda (BS) $\rightarrow$ bahasa Arab (BA) $\rightarrow$ bahasa Indonesia (BI) - Ini menunjukan presentase bahasa Arab $50 \%$, bahasa Sunda 37,5\% dan bahasa Indonesia 12,5\% memberikan isyarat adanya bahasa Arab sangat dikuasai oleh peceramah. Keadaan ini dapat diartikan ketika memberikan penegasan hukum dan terkandung dalam isi ceramah tersebut adanya unsur keagamaan berarti bahasa Arab lebih memberikan pemahaman yang luas dan mudah dimegerti oleh jamah.

Pada data no 7.1 penggalan ceramah berikut menampakkan peralihan kode dari bahasa Arab ke bahasa Sunda. Awalnya, K.H Jamaludin menggunakan tuturan bahasa Arab ke bahasa Sunda saat menyampaikan materi ceramahnya, tetapi kemudian beralih ke bahasa Arab terutama ketika menyampaikan sebuah konsep penting yang perlu diketahui para jamaahnya. Dalam kalimat berikut adalah kata "niatna" Ini dilakukan karena penceramah ingin mengungkapan tentang suatu pesan hukum dalam agama islam yaitu tentang nikah yang ingin dimengerti oleh para jamaah. kosa kata /niat/ yang berasal dari Bahasa Arab \{ثين merupakan kosa kata Arab yang diserap ke dalam Bahasa Sunda. Kosa kata ini digunakan dan beradaptasai dengan sistem imbuhan berupa sufiks Bahasa Sunda $\{-$ na $\}$ yang bermakna menunjukan keterangan terhadap sesuatu atau seseorang. Pengguaan kata "niatna" niatnya dalam arti bahasa Indonesia, agar para jamaah paham dan mengerti dengan peralihan kode yang dilakukan oleh penceramah dan para jamaah paham dengan konsepsi Bahasa Arab yang sudah mendapat imbuhan \{-na\} dalam Bahasa Sunda.

Pengaruh ini dilakukan tentu saja untuk menyesuaikan kode yang telah digunakan masyarakat pada umumnya dalam menunjukan kepunyaan atau orang ketiga. Agar dapat dipahami oleh jamaah, dan penceramah kembali meggunakan bahasa yang kasar ketika berbicara kepada para jamaah, karea perlihan kode diatas dan imbuhan sufiks pada kata "niatna" ditujukan tidak hanya kepada individu jamaah yang menikah akan tetapi kepada para jamaah yang masih muda agar bisa menjadi patokan ketika para pemuda dan pemudi ingin menikah. Ini menunjukan ada undak usuk dalam bahasa sunda. Penggalan kalimatnya adalah : "/Allah(BA) teu resepeun ka jalema anu ngan saukur ngasaan doang, mantak $(B S) \rightarrow$ niatna $(B A) \rightarrow$ heula baguskeun (BS)/". Dalam bahasa indonesia berarti Allah tidak menyukai terhadap orang yang hanya sebatas keinginan saja, maka dari itu harus memiliki niat yang bagus terlebih dahulu.

Kalimat diatas adanya sufiks $\{-n a\}$ penggunaan imbuhan ini memberikan makna sebuah kepuyaan dan fungsinya adalah mempertegas suatu tuturan penceramah dalam menjelaskan isi ceramah tersebut, kalimat penggalan diatas meunjukan pealihan bahasa yang berjumlah empat kali alih kode yang dilakukan dan menggunakan dua bahasa diawali bahasa Arab (BA) $\rightarrow$ bahasa Sunda (BS) $\rightarrow$ bahasa Arab (BA) $\rightarrow$ bahasa Sunda (BS). Ini menunjukan presentase bahasa Arab $50 \%$, bahasa Sunda $50 \%$ memberikan isyarat adanya bahasa Arab dan bahasa Sunda keduaduanya dikuasai oleh peceramah. Keadaan ini dapat diartikan ketika 
memberikan analogi sebuah hokum dalam pernikahan yang terkandung dalam isi ceramah tersebut bias diimbangi dalam pemahaman yang luas dan mudah dimegerti oleh jamah.

Penggunaan bahasa yang dilakukan oleh K.H Jamaludin dalam ceramah keagamaan bahasa Sunda sebenarnya bahasa Sundalah yang dominan dalam ceramah tersebut, megacu pada penelitian tentang penggunaan bahasa Arab yang terdapat dalam ceramah keagmaan Bahasa Sunda K.H Jamaludin, penggunaan bahasa Arab pada masyarakat Banten hususnya masyarakat Pandeglang masih sangat diperhitungkan dan dekategorikan sebagai bahasa yang utama dalam pembahasan konsep-konsep keagamaan.

\section{Faktor-faktor terjadinya Alih Kode}

Di dalam penelitian ini, ditemukan empat faktor penyebab terjadinya peralihan kode BS, BA dan BI. Temuan penelitian ini berbeda dengan penelitian Sri Sutrisni (2005) yang menemukan delapan faktor penyebab terjadinya alih kode yaitu (1) kemarahan terhadap pembeli, (2) kejengkela pembeli pada penjual, (3) mempuyai maksud tertentu, (4) menyesuaikan dengan kode yang dipakai pembeli, (5) ekspresi keterkeutan pembeli, (6) kehadiran calon pembeli lain pada saat tawarmenawar berlangsung, (7) bercanda dengan pembeli, (8) basa-basi penjual pada pembeli. Berdasarkan pengamatan dan analisis data variasi bahasa dan tipe pengguaan bahasa yang diperoleh melaui rekaman video ditemukan faktorfaktor penyebab itu sebagai berikut : 1) faktor situasi, 2) faktor kejiwaan, 3) politik bahasa dan politik islam.

\section{Faktor situasi}

Pilihan sebagai pengaruh situasi, terjadi pada ceramah keagamaan K.H Jamaludin Pandeglang baik linguistik ataupun nonlinguistik. Situasi merupakan salah satu faktor yang menentukan variasi bahasa didalam penelitian ini dimaksud posisi, posisiposisi ini yang menyebabkan peralihan kode dalam ceramah keagamaan bahasa Sunda K.H Jamaludin dibagi menjadi dua posisi yang pertama posisi pada ceramah yang bertema sosial dan yang kedua bertemakan moral.

Para jamaah yang memiliki ragam suku sangat jelas peceramah menggunakan alih kode karena pertimbangan mitra tuturnya yaitu para jamaah. Berbagai alih kode dilakukan oleh penutur tergantung situasi dalam ceramahya, analisis dilakukan mulai dari data no 1 dari tabel 1.1 sampai 20.1 dan data no 2 dari tabel 1.2 sampai 27.2, dan penceramah berperan penting dalam teradinya alih kode oleh penceramah. ${ }^{14}$

\section{Faktor kejiwaan}

Ada lima ciri faktor kejiwaan yang menjadi faktor peralihan kode yang diamati oleh peneliti yaitu : 1) suka tidak suka, 2) pemenuhan kebutuhan pribadi, 3) perasaan sebagai teman sebaya, 4) kebiasaan, 5) bakat.

\footnotetext{
${ }^{14}$ (Amalia Rizqi Khoiriyah, 2012) menggambarkan bentuk-bentuk, faktor-faktor dan jenis alih kode dan campur kode dalam kehidupan tindak tutur bahasa karakter dalam komik ini. Data yang dianalisis adalah kata-kata, frase idiom, dan klausa. Dalam analisis, banyak diperoleh bentuk alih kode dan campur kode dalam bahasa lain selain bahasa Jepang dalam pidato karakter. Bentuk kode campuran yang sering muncul dikategorikan sebagai kata benda. Hasil penelitian menunjukkan bahwa ada 5 jenis alih kode yang digunakan oleh karakter buku komik Nodame Cantabile itu. Mereka adalah: (1
} 
Perasaan suka dan tidak suka

Perasaan suka dan tidak suka dikategorikan sebagai sikap, dalam ceramah K.H Jamaludin terdapat materi ceramah yang disisipi dialog dengan salah satu jamaahnya seperti dalam data no 1.1 penggalan ceramah sebagai berikut : "/bah urang kaditu dei (BS) $\rightarrow$ ngahadiran (BA) $\rightarrow$ Kiyai Asep Mubarok ongkoh dei ngulemna geh ka kyai Zaenal waktos aya abdi (BS)/" arti dalam bahasa Indonesia adalah "Bah saya kesana menghadiri Kiyai Asep Mubarok mengundang juga ke Kiyai Zainal ketika ada saya" dalam penggalan ceramah tersebut peceramah mengutarakan balasan budi dari seseorang yang didasari atas faktor kejiwaan yang senang atau suka atas undangan kepada penceramah. Bisa dianggap pula sebagai pengaruh budaya bahasa yang mempengaruhi terkaitnya sebuah tutur antar penceramah dengan para jamaah.

\section{Pemenuhan kebutuhan pribadi}

Contoh dalam hal ini bisa diambil pada data no 2.1 yaitu : /Begitu (BI) $\rightarrow$ Walimah, Tafarruq (BA) $\rightarrow$ bulan sya'ban terakhir $(B I) \rightarrow$ anjena $(B S)$ naparrukeun $(B A) \rightarrow$ santri $(B I) /$ " salah satu contoh dalam ebahasa Indnesia berarti "Waktu di perayaan ,"Taffaruq" bulan sya'ban terkahir beliau meluluskan santri" dalam kutipan ceramah ini bias kita lihat bahwasanya penceramah meelaskan gambaran seseorang yang sedang melaksanakan acara pribadi dan dalam penggalan cerimah berikutnya pada data no 1 tabel2,1.3,1.4 dan 1.5 tersirat keinginan dan tujuan penceramah dalam bahasanya yang halus ingin bisa difahami oleh salah satu jamaah yang tidak lain adalah calon besan dari kerabat penceramah.
Perasaan akrab pada pendengar

Perasaan akrab dikategorikan sebagai sikap, dalam ceramah K.H Jamaludin terdapat materi ceramah yang disisipi dialog dengan salah satu jamaahnya seperti dalam data no 13.1 penggalan ceramah sebagai berikut

"/Makana numawi (BS) $\rightarrow$ ibu bapak (BI) $\rightarrow$ hadirin (BA) punten kang H. Adad Neng Ela $(B S) \rightarrow$ tujuan $(B I) \rightarrow$ nikah $(B A) \rightarrow$ kadua $(B S) \rightarrow$ memperbanyak $(B I) \rightarrow$ ummat rasul $(B A) \rightarrow$ mugamuga putera puteri urang $(B S) \rightarrow$ disarolehkeun $(B A) \rightarrow k u(B S) \rightarrow$ Allah $(B A) /$ " arti dalam bahasa Indonesia "Makanya agar ibu bapak Hadirin, maaf kang H. Adad Neng Ela tujuan Nikah nu kadua memperbanyak Ummat Rasul moga-moga putera-puteri kita menjadi Saleh".

K.H Jamaludin menggunakan tuturan bahasa Sunda saat menyampaikan materi ceramahnya, tetapi kemudian beralih ke bahasa Arab terutama ketika menyampaikan sebuah konsep penting yang perlu diketahui para jamaahnya. Ini dilakukan karena antar penceramah dan para jamaah memang sudah akrab sehingga tidak berjarak. Melihat para jamaah paham dengan konsepsi Bahasa Arab yang sudah mendapat imbuhan \{di+eun\} Bahasa Sunda, para jamaahpun akhirnya mengikuti menggunakan bahasa yang sama. Ini dilakukan tentu saja untuk menyesuaikan kode yang telah digunakan masyarakat pada umumnya dan K.H Jamaludin sebagai publik figur menggunakannya secara berulang agar komunikasi dakwahnya tetap berjalan dan dapat dipahami oleh jamaah. Penggalan percakapan berikut ini mengandung peralihan alih kode dari bahasa Indonesia, Bahasa Arab ke dalam bahasa Sunda yang digunakan 
K.H Jamaludin. dan K.H Jamaludin meggunakan bahasa yang halus ketika berbicara kepada berdialog dengan salah satu jamaah yang lebih tua. Ini menunjukan ada undak usuk dalam bahasa sunda.

\section{Kebiasaan}

Kebiasaan meggunakan bahasa Arab dalam ceramah keagamaan yangn dilakukan oleh penceramah dilakukan ketika dalam menerangkan istilah istilah hukum agama Islam yang menggunakan bahasa Arab conth seperti pada data no 19.1 “'Barang $(B S) \rightarrow$ haram wasilah pertikahan $(B A) \rightarrow$ jadi $(B I) \rightarrow$ halal alhamdulillah (BA)/" arti dalam bahasa Indonesia adalah "Sesuatu yang Haram dengan wasilah pernikahan menjadi Halal Alhamdulillah". Menjadi suatu kebiasaa ketika orang Sunda meggunakan bahasa Arab ketika menerangkan hukum dan penjelasan menggunakan bahasa Sunda. ${ }^{15}$

\section{Bakat}

Bakat yang dimiliki oleh penceramah adalah berkempuan menggunakan lebih dari satu bahasa, yaitu penceramah bisa mengguakan bahasa Sunda, bahasa Arab dan bahasa Indonesia. contoh terdapat dalam penggalan kalimat dalam ceramah sebagai berikut : data no 14.2 terdapat bahasa Arab yang utuh yang penceramah utarakan dalam ceramahnya.

\section{Faktor Politik}

\section{Politik bahasa}

Berbicara politik bahasa tidak jauh dari tiga aspek yang pertama, yakni dari pelafalan, kosa kata dan tata bahasa, aspek yang kedua adalah aspek status planning, yaitu berkaitan dengan kedudukan bahasa Sunda dalam bahasa lainya seperti baha Arab dan bahasa Indonesia. ${ }^{16}$ Dalam data secara keseluruhan aspek yang kedua ini sangat digenggam erat oleh penceramah karena eksistensi beliau selalu konsisten menggunakan bahasa Sunda di daerah di luar Pandeglang sekalipun, dan aspek yang ketiga perolehan bahasa, yaitu bagaimana bahasa Sunda, bahasa Arab dan Indonesia diajarkan di satu daerah yaitu dalam konteks ini adalah Pandeglang, penceramah adalah seorang ulama atau publik figur dan pemerolehan bahasa yang beliau adalah pertama dari belajar di Pesantren dan di masyarakat secara umum.

Dalam ceramah keagamaan berbahasa Sunda di Pandeglang yang dilakukan oleh K.H Jamaludin dengan baik menggunakan ketiga aspek di atas sebagai identitas sosial beliau agar para jamaah bisa menilai bahwasanya beliau adalah seorang ulama yang kuat akan segala keilmuan agama karena ketiga aspek tadi, menunjang seluruh materi ceramah yang dikemukan, dan masyarakata faham aka materi yang disampaiakan.

\section{Pemikirann Politik islam dalam ceramah}

Dalam ceramah keagamaan berbahasa Sunda di Pandeglang yang dilakukan oleh K.H Jamaludin, ini adalah sebuah dakwah islamiyah yang bermuatan Agama murni namun dalam bahasa yang dilakukan oleh peceramah dan sikap yang terdapat pada penceramah akan menggambarkan kesan dan pesan moral juga banyak materimateri ceramah yang bersinggungan dengan persaudaraan, hukum islam dan sunatullah yang disampaikan pada isian ceramah tersebut. didalamnya terdapat tujuan untuk lebih mendekatkan diri kepada Allah meyakini tuhan

${ }^{16}$ (A. Chaedar Alwasilah, 1997) 
yang satu, ${ }^{17}$ serta anjuran melakukan sunatullah dan menyamaratakan kita semua adalah hamba Allah yang patut berlutut di hadapaNya.

Fungsi Alih Kode

Beberapa fungsi Alih Kode yang ditemukan dalam CKBSP di Pandeglang Banten, adalah : (1) Lebih persuasif membujuk atau menyuruh mitra tutur, (2) lebih argumentatif meyakinkan mitra tutur, (3) lebih komunikatif dalam menjelaskan, (4) membangkitkan simpatik, sebagaimana yang telah diklasifikasikan oleh peneliti yaitu sebagai berikut :

Persuasif Membujuk, Merayu Atau Menyuruh Mitra Tutur

Ibah urang kaditu dei (BS) $\rightarrow$ ngahadiran (BA) $\rightarrow$ kiyai asep mubarok ongkoh dei ngulemna geh ka kyai zaenal waktos aya abdi (BS)/

Terjemah (BI) : Bah saya kesana menghadiri Kiyai Asep Mubarok mengundang juga ke Kiyai Zaenal ketika ada saya.

Data (No. 1.1 ) Penggalan percakapan di atas menyampaikan peralihan kode dari bahasa Sunda ke bahasa Arab. Awalnya, K.H Jamaludin menggunakan tuturan bahasa Sunda saat menyampaikan materi ceramahnya, tetapi kemudian beralih ke bahasa Arab terutama ketika menyampaikan sebuah konsep penting yang perlu diketahui oleh salah satu jamaah yang mendegarkan, beliau mencoba berkmunikasi dan berinteraksi melakukan ajakan ke suatu tempat yang akan beliau tuju. Dan fungsi lain adalah ini sebagai fungsi Akhlak yang beliau ingin sampaikan dalam ceramahya.

\footnotetext{
${ }^{17}$ (Sukron Kamil, 2013)
}

/pang didikeun pang elmuankeun rai pribados nu jenenganana. $H$ Hasan Musaddad oge kedah (BS) $\rightarrow$ memaklumi $(B A) \rightarrow$ kaayaan $(B S) \rightarrow$ sipatna $(B A) \rightarrow$ nu kos kitu $(B S) /$

Terjemah BI : Mohon untuk dididik dan diberi ilmu adik saya, dan $\mathrm{H}$ Hasan Musadad harus memaklumi terhadap sifatnya yang seperti itu lebih argumentatif meyakinkan mitra tutur

Data (No. 1.5) Penggalan percakapan di atas menyampaikan peralihan kode dari bahasa Sunda ke bahasa Arab. Awalnya, K.H Jamaludin menggunakan tuturan bahasa Sunda saat menyampaikan materi ceramahnya, tetapi kemudian beralih ke bahasa Arab terutama ketika menyampaikan sebuah konsep penting yang perlu diketahui oleh salah satu jamaah yang mendegarkan, beliau mencoba berkmunikasi dan berinteraksi melakukan rayuan kepada salah satu jamaah dan memiliki keinginan. Kare Dan fungsi lain adalah ini sebagai fungsi Akhlak yang beliau ingin sampaikan dalam ceramahya.

llangkung tipayun mangga urang sadaya sasarengan muji $(B S) \rightarrow$ tasyakur $(B A)$ $\rightarrow k a(B S) \rightarrow$ Allah $(B A) \rightarrow$ nu maha $(B S) \rightarrow$ ghafur $(B A) /$

Terjemah BI : Pertama-tama marilah kita bersama-sama memnjatkan puji sukur kepada Allah nu maha Ghafur.

Data (No. 2.1 ) Penggalan ceramah di atas menyampaikan peralihan kode dari bahasa Sunda ke bahasa Arab. Awalnya, K.H Jamaludin menggunakan tuturan bahasa Sunda saat menyampaikan materi ceramahnya, tetapi kemudian beralih ke bahasa Arab terutama ketika menyampaikan sebuah konsep penting yang perlu diketahui oleh jamaah 
yang mendegarkan, beliau mencoba berinteraksi melakukan ajakan untuk memuji Allah. Dan fungsi lain adalah ini sebagai fungsi Akhlak yang beliau ingin sampaikan dalam ceramahya.

lumumna $(B A) \rightarrow$ nu $(B S) \rightarrow$ hadir $(B A)$ $\rightarrow$ wengi ie $(B S) \rightarrow$ khususil khusus almukarram (BA) $\rightarrow$ guru urang KH.Rafi' $i$ mudah-mudahan mantena ku (BS) $\rightarrow$ Allah $(B A) \rightarrow$ sing enggal dipasihan $(B S) \rightarrow$ kesehatan $(B I) /$

Data (No. 2.2 ) Penggalan percakapan di atas menyampaikan peralihan kode dari bahasa Arab ke bahasa Sunda. Awalnya, K.H Jamaludin menggunakan tuturan bahasa Arab saat menyampaikan materi ceramahnya, tetapi kemudian beralih ke bahasa Sunda dan kembali menggunakan bahasa Arab terutama ketika menyampaikan sebuah konsep penting yang perlu diketahui oleh salah satu jamaah yang mendegarkan, beliau mencoba berkmunikasi dan berinteraksi melakukan rayuan kepada salah satu jamaah dan memiliki keinginan. Dan fungsi lain adalah ini sebagai fungsi Akhlak yang beliau ingin sampaikan dalam ceramahya.

mudah-mudahanku(BS) $\rightarrow$ Allahhajatna $(B A) \rightarrow \operatorname{sing}(B S) \rightarrow$ dibarokahkeun $(B A), \rightarrow$ puterana mudah-mudahan $k u(B S) \rightarrow$ Allah $(B A) \rightarrow$ sing didamel putera anu $(B S) \rightarrow$ saroleh $(B A)$

Terjemah BI : Mudah-mudahan oleh Allah Acarana semoga diberkahi, anakanaknya mudah-mudahan oleh Allah dijadikan anak yang Saleh

Data (No.2.3 ) Penggalan ceramah di atas menyampaikan peralihan kode dari bahasa Sunda ke bahasa Arab. Awalnya, K.H Jamaludin menggunakan tuturan bahasa Sunda saat menyampaikan materi ceramahnya, tetapi kemudian beralih ke bahasa Arab terutama ketika menyampaikan sebuah konsep penting yang perlu jamaah yang mendegarkan, beliau mencoba berkmunikasi dan berinteraksi melakukan munajat berdoa kepada Allah untuk sepasang pengantin, hal ini dilakukan agar dapat ditiru oleh para jamaah. Dan fungsi lain adalah ini sebagai fungsi Akhlak yang beliau ingin sampaikan dalam ceramahya.

/bener-bener(BS) $\rightarrow$ tobatna $(\mathrm{BA}) \rightarrow$ $\operatorname{para}(\mathrm{BI}) \rightarrow$ hadirin $(\mathrm{BA}) \rightarrow \operatorname{sadaya}(\mathrm{BS})$.

Terjemah BI : Benar-benar tobatnya para hadirin semua.

Data (No. 2.22 ) Penggalan percakapan di atas menyampaikan peralihan kode dari bahasa Sunda kemudian ke bahasa Arab. Awalnya, K.H Jamaludin menggunakan tuturan bahasa Sunda saat menyampaikan materi ceramahnya, tetapi kemudian beralih ke bahasa Arab terutama ketika menyampaikan sebuah konsep penting yang perlu diketahui oleh salah satu jamaah yang mendengarkan, beliau mencoba berkomunikasi dan berinteraksi melakukan rayuan kepada salah satu jamaah untuk lebih medekatkan diri dan bertaubat kepada Allah.

hayang menta $(B S) \rightarrow$ doana $(B A) \rightarrow k a$ para $(B S)$ jamaah $(B A)$ /

Terjemah BI : Ingin meminta doanya kepada para jamaah.

Data (No. 2.26 ) Penggalan percakapan di atas menyampaikan peralihan kode dari bahasa Sunda kemudian ke bahasa Arab. Awalnya, K.H Jamaludin menggunakan tuturan bahasa Sunda saat menyampaikan materi ceramahnya, tetapi kemudian beralih ke bahasa Arab 
terutama ketika menyampaikan sebuah konsep penting yang perlu diketahui oleh salah satu jamaah yang mendegarkan, beliau mencoba berkomunikasi dan berinteraksi melakukan rayuan kepada salah satu jamaah agar apa yang diinginkan oleh penceramah bisa dikabul oleh Allah karena doa dari para jamaah, fungsi Alih Kode sebgai cara agar para jamaah mau mendoakan penceramah.

Argumentatif Meyakinkan Mitra Tutur

/begitu $(B I) \rightarrow$ walimah, tafarruq (BA) $\rightarrow$ bulan sya'ban terakhir $(B I) \rightarrow$ anjena $(B S)$ naparrukeun $(b a) \rightarrow$ santri $(B I) /$

Terjemah BI : Waktu di perayaan "Taffaruq" bulan sya'ban terkahir beliau meluluskan santri.

Data (No. 1.2 ) Penggalan ceramah di atas menyampaikan peralihan kode dari bahasa Sunda ke bahasa Arab. Awalnya, K.H Jamaludin menggunakan tuturan bahasa Sunda saat menyampaikan materi ceramahnya, tetapi kemudian beralih ke bahasa Arab terutama ketika menyampaikan sebuah konsep penting yang perlu diketahui jamaah yang mendegarkan, beliau mencoba meyakinkan keadaan yang lampau yang telah teradi, yaitu beliau mengadakan suatu acara perpisahan di Pesantrenya. Dan fungsi lain adalah sebagai Akhlak karena ini suatu peristiwa pedidikan yang memliki kelanjutan dan beliau sebagai guru wajib memberikan tanda atau sertifkasi kelulusan terhadap muridnya.

Iterus $(B I) \rightarrow$ tah meren ges $(B S) \rightarrow$ qudrat iradahna allah disababiyahan $(B A) \rightarrow k u$ kula begitu ondangan $k a$ kebon kalapa (BS)/

Terjemah BI : Terus itu sudah menjadi taqdir baik ataupun buruk dan disebabkan oleh saya ketika undangan ke Kebon Kelapa.

Data (No. 1.3 ) Penggalan ceramah di atas menyampaikan peralihan kode dari bahasa Indonesia ke bahasa Sunda kemudian ke bahasa Arab. Awalnya, K.H Jamaludin menggunakan tuturan bahasa Indnesia saat menyampaikan materi ceramahnya, tetapi kemudian beralih ke bahasa Sunda dan Arab terutama ketika menyampaikan sebuah konsep penting yang perlu diketahui jamaah yaitu sebuah hokum qudrat dari Allah yang perlu diyakini oleh para jamaah, karena ini kembali kepada keimanan. K.H Jamaludin mencoba meyakinkan para jamaah dengan mengguakan peralihan bahasa Arab. Dan fungsi lain adalah fungsi Hukum Allah knsep keimanan yang perlu ditanamkan oleh para jamaah.

lalhamdulillah dikudrotkeun $(B A) \rightarrow$ jeng $(B S) \rightarrow$ diirodatkeun $(B A) \rightarrow k u$ $(B S) \rightarrow$ Allah $(B A) \rightarrow$ sahingga cariosan $(B S) \rightarrow \operatorname{almarhum}(B A) \rightarrow$ tercapai $(B I) /$

Terjemah BI : Alhamdulillah semoga ditaqdirkan baik ataupun buruknya oleh Allah sehingga harapan dari pembicaraan dengan Almarhum dapat tercapai.

Data (No. 1.4 ) Penggalan ceramah di atas menyampaikan peralihan kode dari bahasa Arab ke bahasa Sunda kemudian ke bahasa Arab. Awalnya, K.H Jamaludin menggunakan tuturan bahasa Arab saat menyampaikan materi ceramahnya, tetapi kemudian beralih ke bahasa Sunda dan Arab terutama ketika menyampaikan sebuah konsep penting yang perlu diketahui jamaah yaitu sebuah hukum irodah dari Allah yang perlu diyakini oleh para jamaah, karena ini kembali kepada keimanan. K.H Jamaludin mencoba meyakinkan para 
jamaah dengan mengguakan peralihan bahasa Arab. Dan fungsi lain adalah fungsi Hukum Allah knsep keimanan yang perlu ditanamkan oleh para jamaah.

IAllah(BA) Allah teu resepeun ka jalema anu ngan saukur ngasaan doang, mantak $(B S) \rightarrow$ niatna $(B A) \rightarrow$ heula baguskeun (BS)/

Terjemah BI : Allah tidak menyukai terhadap orang yang hanya sebatas keinginan saja, maka dari itu harus memiliki niat yang bagus terlebih dahulu.

Data (No. 1.7 ) Penggalan ceramah di atas menyampaikan peralihan kode dari bahasa Arab ke bahasa Sunda kemudian ke bahasa Arab. Awalnya, K.H Jamaludin menggunakan tuturan bahasa Arab saat menyampaikan materi ceramahnya, tetapi kemudian beralih ke bahasa Sunda dan Arab terutama ketika menyampaikan sebuah konsep penting yang perlu diketahui jamaah yaitu sebuah konsep keagamaan apabila para jamaah menginginkan sebuah sesuatu terus mendapat berkah dan kebaikan yaitu K.H Jamaludin mengajak untuk memperbaiki niat terlebih dahulu. Dan fungsi lain ini adalah sebuah etika atau akhlak ketika kita memiliki permintaan kepada Allah.

Igeura $(B S) \rightarrow$ nararikah $(B A) \rightarrow$ anjeun teangan anu $(B S)$ waluud $(B A) \rightarrow n u$ ngabadeg turunanana (BS)/

Terjemah BI : Disegerakan menikah kalian, carilah yang (banyak ankanya) yang banyak turunanya.

Data (No. 1.8 ) Penggalan ceramah di atas menyampaikan peralihan kode dari bahasa Sunda kemudian ke bahasa Arab. Awalnya, K.H Jamaludin menggunakan tuturan bahasa Sunda saat menyampaikan materi ceramahnya, tetapi kemudian beralih ke bahasa Arab terutama ketika menyampaikan sebuah konsep penting yang perlu diketahui jamaah yaitu sebuah hukum dalam melakukan kehidupan dan berhubungan antar lawan jenis harus ada status yang sah yaitu sebuah pernikahan. K.H Jamaludin sangat komunikatif agar pesan hukum tersampaikan kepada jamaah hususnya kepada para pemuda dan pemudi.

Imuga-muga ku $(B S) \rightarrow$ Allah $(B A) \rightarrow$ sing $(B S) \rightarrow$ disarolehkeun amiin $(B A) /$

Terjemah BI : Mudah-mudahan oleh Allah dijadikan Saleh dan Salihah Amin.

Data (No. 1. 9 ) Penggalan ceramah di atas menyampaikan peralihan kode dari bahasa Sunda ke bahasa Arab. Awalnya, K.H Jamaludin menggunakan tuturan bahasa Sunda saat menyampaikan materi ceramahnya, tetapi kemudian beralih ke bahasa Arab terutama ketika menyampaikan sebuah konsep penting yang perlu diketahui oleh jamaah yang mendengarkan, dalam penggalan ceramah ini beliau bermunajat untuk para jamaah menyampaikan sebuah keinginan kepada Allah. Dan fungsi lain adalah sebagai Akhlak beliau ketika melakukan permintaan kepada Allah.

lasupken kadaharan nu (BS) $\rightarrow$ diharamkeun $(B A) \rightarrow$ cek $(B S) \rightarrow$ pendapat agama (BI)/

Terjemah BI : Memasukan makanan yang diharamkan menurut pendapat Agama.

Data (No. 1.10 ) Penggalan ceramah di atas menyampaikan peralihan kode dari bahasa Sunda kemudian ke bahasa Arab. Awalnya, K.H Jamaludin menggunakan tuturan bahasa Sunda 
saat menyampaikan materi ceramahnya, tetapi kemudian beralih ke bahasa Arab terutama ketika menyampaikan sebuah konsep penting yang perlu diketahui jamaah yaitu sebuah konsep hukum dalam Agama. K.H Jamaludin sangat komunikatif agar pesan hukum tersampaikan kepada jamaah hususnya kepada para jamaah.

/kalah ka deugeul bae barang daharna teu dipikiran $(B S) \rightarrow$ halal $(B A) \rightarrow$ jeung $(B S) \rightarrow$ haramna $(B A) /$

Terjemah BI : Malah makin nakal, karena makanya tidak dipikirkan Halal dan Haramnya.

Data (No. 1.11 ) Penggalan ceramah di atas menyampaikan peralihan kode dari bahasa Sunda kemudian ke bahasa Arab. Awalnya, K.H Jamaludin menggunakan tuturan bahasa Sunda saat menyampaikan materi ceramahnya, tetapi kemudian beralih ke bahasa Arab terutama ketika menyampaikan sebuah konsep penting yang perlu diketahui jamaah yaitu sebuah konsep hukum dalam Agama. K.H Jamaludin sangat komunikatif agar pesan hukum tersampaikan kepada jamaah hususnya kepada para jamaah.

Imakana numawi (BS) $\rightarrow$ ibu bapak (BI) $\rightarrow$ hadirin (BA) punten kang $H$. Adad Neng Ela $(B S) \rightarrow$ tujuan $(B I) \rightarrow$ nikah $(B A) \rightarrow$ kadua $(B S) \rightarrow$ memperbanyak $(B I) \rightarrow$ ummat rasul $(B A) \rightarrow$ mugamuga putera puteri urang $(B S) \rightarrow$ disarolehkeun $(B A) \rightarrow k u(B S) \rightarrow$ Allah (BA)/

Terjemah BI : Makanya agar ibu bapak Hadirin, maaf kang H. Adad Neng Ela tujuan Nikah nu kadua memperbanyak Ummat Rasul moga-moga putera-puteri kita menjadi Saleh
Data (No. 1.13 ) Penggalan ceramah di atas menyampaikan peralihan kode dari bahasa Sunda ke bahasa Arab. Awalnya, K.H Jamaludin menggunakan tuturan bahasa Sunda saat menyampaikan materi ceramahnya, tetapi kemudian beralih ke bahasa Arab terutama ketika menyampaikan sebuah konsep penting yang perlu diketahui oleh jamaah yang mendengarkan, dalam penggalan ceramah ini beliau bermunajat untuk para jamaah menyampaikan sebuah keinginan kepada Allah. Dan fungsi lain adalah sebagai Akhlak beliau ketika melakukan permintaan kepada Allah.

/pastina geh mun urang hayang loba $(B S) \rightarrow$ rizqi $(B A) \rightarrow \operatorname{sing}(B S) \rightarrow$ rajin $(B I) \rightarrow$ sholat $(B A) \rightarrow$ dhuha $(B A) \rightarrow$ bener te? Lamun hayang di angkat (BS) $\rightarrow$ darajat $(B A) \rightarrow$ sing $(B S) \rightarrow$ rajin $(B I) \rightarrow$ shalat tahajjudna $(B A) /$

Terjemah BI : Pastinya kalau kita ingin banyak rizqi, yang rajin shalat Dhuha betul tidak ? kalau ingin diangkat derajat, rajin Shalat tahajudnya.

Data (No. 1.14) Penggalan ceramah n di atas menyampaikan peralihan kode dari bahasa Sunda ke bahasa Arab. Awalnya, K.H Jamaludin menggunakan tuturan bahasa Sunda saat menyampaikan materi ceramahnya, tetapi kemudian beralih ke bahasa Arab terutama ketika menyampaikan sebuah konsep penting yang perlu diketahui oleh jamaah yang mendengarkan, dalam penggalan ceramah ini beliau mejelaskan manfaat dan hikmah beribadah beliau juga bermunajat untuk para jamaah menyampaikan sebuah keinginan kepada Allah. Dan fungsi lain adalah sebagai Akhlak beliau ketika melakukan permintaan kepada Allah.

Ikalau ingin $(B I) \rightarrow$ rizkina $(B A) \rightarrow$ 
kontan (BI), $\rightarrow$ shalat mayit (BA)/

Terjemah BI : Kalau ingin rizqina kontan, shalat mayit.

Data (No. 1.15 ) Penggalan ceramah di atas menyampaikan peralihan kode dari bahasa Sunda ke bahasa Arab. Awalnya, K.H Jamaludin menggunakan tuturan bahasa Sunda saat menyampaikan materi ceramahnya, tetapi kemudian beralih ke bahasa Arab terutama ketika menyampaikan sebuah konsep penting yang perlu diketahui oleh jamaah yang mendengarkan, dalam penggalan ceramah ini beliau mejelaskan manfaat dan hikmah beribadah beliau juga bermunajat untuk para jamaah menyampaikan sebuah keinginan kepada Allah. Dan fungsi lain adalah sebagai Akhlak beliau ketika melakukan permintaan kepada Allah.

/laju tah lamun kitu $(B S) \rightarrow$ akhlakna $(B A) \rightarrow$ tah urang $(B S) \rightarrow$ maka $(B I) \rightarrow$ $k u d u(B S) \rightarrow$ mahabbah $(\mathrm{BA}) \rightarrow$ resep ka jalema anu $(\mathrm{BS}) \rightarrow$ shaleh $(\mathrm{BA}) /$

Terjemah BI : Kemudian kalau seperti itu Akhlaknya saya harus menyukai kepada orang yang Saleh.

Data (No. 1.20 ) Penggalan ceramah di atas menyampaikan peralihan kode dari bahasa Sunda ke bahasa Arab. Awalnya, K.H Jamaludin menggunakan tuturan bahasa Sunda saat menyampaikan materi ceramahnya, tetapi kemudian beralih ke bahasa Arab terutama ketika menyampaikan sebuah konsep penting yang perlu diketahui jamaah yang mendegarkan, beliau mencoba meyakinkan para jamaah akan konsep mahabah. Anjuran dan ajakan beliau agar para jamah medekatkan diri dan bergaul dengan orang-orang yang shaleh. Dan fungsi dari penggala ceramah diatas adalah sebagai Akhlak /sakitu anu ngamparna, gunung sakitu anu luhurna teu daekeun narima(BS) $\rightarrow \operatorname{amanat}(B A) \rightarrow t i(B S) \rightarrow$ allah $\operatorname{akhirna}(B A) \rightarrow$

$$
\text { و حملها الإنسان } \rightarrow \text { (BA) }
$$

ditawarken $k u(B S) \rightarrow \operatorname{allah}(B A) \rightarrow$ $k a(B S) \rightarrow$ manusia $(B I) \rightarrow$ nyatana $(B S)$ $\rightarrow$ nabiyullah Adam $A S(B A) \rightarrow$, ceuk $(B S) \rightarrow$ nabiyullah Adam AS $(B A) \rightarrow$, ceuk $(B S)$ allah $(B A) \rightarrow$ Dam daek dia narima $(B S) \rightarrow \operatorname{amanat}(B A) \rightarrow$ ti aing? Naon gusti? $(B S) \rightarrow$ katakan $(B I) \rightarrow$

$$
\text { أركان الإسلامج (BA) }
$$

shalat $(B A) \rightarrow$ nu bener $(B S) . \rightarrow$ zakat, haji, shadaqah (BA), $\rightarrow$ ngadidik anak, daek tah hente? Cek $(B S) \rightarrow$ nabi Adam (BA), $\rightarrow$ ari kitu kumaha gusti (BS)/

Terjemah BI : Sebegitu luasnya, gunung yang begitu tingginya tidak mau menerima amanat dari Allah akhirna.

"Dibawa Amanat Itu Kepada Manusia"

diatawarkan oleh Allah kepada manusia ternyata Nabi Allah Adam AS, Nabi Adam berkata, Allah berkata dan apakah kamu mau menerima amanat dari-Ku? Apa tuhan? katakan

"rukun Islam" shalat yang benar. Zakat, Haji, mendidik anak, mau tidak? Nabi Adam berkata : Kalau Seperti Itu, bagaimana Tuhan?.

Data (No. 2.4 ) Penggalan ceramah di atas menyampaikan peralihan kode dari bahasa Sunda ke bahasa Arab. Awalnya, K.H Jamaludin menggunakan tuturan bahasa Sunda saat menyampaikan materi ceramahnya, tetapi kemudian beralih ke bahasa Arab terutama ketika menyampaikan sebuah konsep 
penting yang perlu diketahui jamaah yang mendegarkan, beliau mencoba meyakinkan para jamaah akan konsep sebuah amanah yang diberikan oleh Allah kepada manusia, dalam penggalan ceramah ini K.HJamaludin menceritakan tentang kemulian manusia yang siap dan mau menerima amanat dari Allah, cerita ini menelaskan bahwasanya manusia adalah makhluk yang paling mulia diatara makhluk Allah lainya.

/hirup di $(B S) \rightarrow$ alam dunia $(B A) \rightarrow n u$ te lok $(B S)$ shalat $(B A) \rightarrow$ geh hirup di $(B S) \rightarrow$ alam dunia $(B A) \rightarrow$ bahkan $(B I)$ $\rightarrow$ rizkina $(B A) \rightarrow$ lewih loba ti jalema anu sok $(B S) \rightarrow$ shalat $(B A) /$

Terjemah BI : Hidup di alam dunia, yang tidak suka shalat pun hidup di alam dunia bahkan rizqinya lebih banyak dari orang yang suka shalat.

Data (No. 2.7) Penggalan ceramah di atas menyampaikan peralihan kode dari bahasa Sunda ke bahasa Arab. Awalnya, K.H Jamaludin menggunakan tuturan bahasa Sunda saat menyampaikan materi ceramahnya, tetapi kemudian beralih ke bahasa Arab terutama ketika menyampaikan sebuah konsep penting yang perlu diketahui jamaah yang mendegarkan, beliau mencoba meyakinkan para jamaah akan konsep sebuah amanah yang diberikan oleh Allah kepada manusia, K.H Jamaludin menganalogikan tentang realita hidup dengan konsep hukum dalam agama, yaitu seorang manusia yang tidak beribadah dan giat beribadah akan disama ratakan dalam hal rizki, tapi maksud penggalan ceramah diatas aka nada hal yang bereda dari sudut pandang hokum agama dan Allah yaitu amalan-amalan ibadahnya. Karena di mata Allah manusia dibedakan akan iman dan taqwa. Konsep fungsi hokum disini adalah amanah ibadah yang harus dilakukan oleh para jamaah dengan sungguh-sungguh dan penuh keikhlasan.

/hakekatna $(B A) \rightarrow$ numpang ka nu sok $(B S) \rightarrow$ shalat $(B A), \rightarrow$ nu te lok ngaji hirup di $(B S) \rightarrow$ alam dunia hakekatna $(B A) \rightarrow$ numpang ka nu sok ngaji (BS)/

Terjemah BI : Hakikatnya menumpang kepada orang yang suka shalat, yang tidak suka ngaji hidup di alam dunia hakikatnya menumpang kepada orang yang suka ngaji.

Data (No. 2.8 ) Penggalan ceramah di atas menyampaikan peralihan kode dari bahasa Arab ke bahasa Sunda. Awalnya, K.H Jamaludin menggunakan tuturan bahasa Arab menyampaikan materi ceramahnya, tetapi kemudian beralih ke bahasa Sunda dan kembali menggunakan bahasa Arab terutama ketika menyampaikan sebuah konsep penting yang perlu diketahui jamaah yang mendegarkan, beliau mencoba meyakinkan para jamaah akan konsep sebuah amanah yang diberikan oleh Allah kepada manusia, dalam penggalan ceramah ini K.H Jamaludin menceritakan bahwasan orang yang tidak beribadah adalah orang yang menumpang di dunia terhadap orang yang beribadah, K.H Jamaludin bermaksud mengingatkan bahwasanya kita tidak ada apa-apanya tanpa amalan dalam hidup kita, bekal apa yang akan kita bawa ketika menghadap kembali kepada Allah. Fungsi Alih Kode dalam kontek disini K.H Jamaludin mencoba menegaskan sebuah konsep Hukum.

$/$ Nu te lok $(B S) \rightarrow$ sedekah $(B A) \rightarrow$ hirup $d i(B S) \rightarrow$ alam dunia $(B A) \rightarrow$ bu $(B S)$ $\rightarrow$ hakekatna $(B A) \rightarrow$ numpang bu, ka nu elok $(B S) \rightarrow \operatorname{sodaqoh}(B A) /$ 
Terjemah BI : Yang tidak suka sedekah hidup di alam dunia bu, hakikatnya numpang kepada orang yang tidak suka sedekah.

Data (No. 2.9 ) Penggalan ceramah di atas menyampaikan peralihan kode dari bahasa Sunda. Ke bahasa Arab Awalnya, K.H Jamaludin menggunakan tuturan bahasa Sunda menyampaikan materi ceramahnya, tetapi kemudian beralih ke bahasa Arab terutama ketika menyampaikan sebuah konsep penting yang perlu diketahui jamaah yang mendegarkan, beliau mencoba meyakinkan para jamaah akan konsep sebuah amanah yang diberikan oleh Allah kepada manusia, dalam penggalan ceramah ini K.H Jamaludin menceritakan bahwasan orang yang tidak bersodakoh adalah orang yang menumpang di dunia terhadap orang yang bersodakoh, K.H Jamaludin bermaksud mengingatkan bahwasanya kita tidak ada apa-apanya tanpa amalan dalam hidup kita, bekal apa yang akan kita bawa ketika menghadap kembali kepada Allah. Fungsi Alih Kode dalam kontek disini K.H Jamaludin mencoba menegaskan sebuah konsep Hukum.

$\mathrm{Nu}$ te elok ngaji geh hirup, nu te elok $(B S) \rightarrow$ shalat $(B A) \rightarrow$ geh hirup $(B S)$, $\rightarrow$ hakekatna $(B A) \rightarrow$ numpang ka nu sok $(B S) \rightarrow$ shalat $(B A) \rightarrow$ jeng ka nu sok ngaji (BS).

Terjemah BI : Yang tidak suka mengajipun hidup, yang tidak shalatpun hidup, hakikatnya menumpang kepada orang yang suka shalat dan mengaji.

Data (No. 2.10 ) Penggalan ceramah di atas menyampaikan peralihan kode dari bahasa Sunda. Ke bahasa Arab Awalnya, K.H Jamaludin menggunakan tuturan bahasa Sunda menyampaikan materi ceramahnya, tetapi kemudian beralih ke bahasa Arab terutama ketika menyampaikan sebuah konsep penting yang perlu diketahui jamaah yang mendegarkan, beliau mencoba meyakinkan para jamaah akan konsep sebuah amanah yang diberikan oleh Allah kepada manusia, dalam penggalan ceramah ini K.H Jamaludin menceritakan bahwasan orang yang tidak Shalat dan ngaji adalah orang yang menumpang di dunia terhadap orang yang Shalat dan ngaji, K.H Jamaludin bermaksud mengingatkan bahwasanya kita tidak ada apa-apanya tanpa amalan dalam hidup kita, bekal apa yang akan kita bawa ketika menghadap kembali kepada Allah. Fungsi Alih Kode dalam kontek disini K.H Jamaludin mencoba menegaskan sebuah konsep Hukum.

/ditarima tah $k u(B S) \rightarrow$ nabi adam $(B A) \rightarrow$ ngan hanjakal $(B S) \rightarrow$

إنه كان ظلوما جهولا mah sok $(B S) \rightarrow$ ngadzalim (BA)/

Terjemah BI : Dierima oleh nabi Adam cuman sayangnya " sesungguhnya manusia itu dzalim dan bodoh" manusia suka dzalim.

Data (No. 2.12) Penggalan ceramah di atas menyampaikan peralihan kode dari bahasa Sunda. Ke bahasa Arab Awalnya, K.H Jamaludin menggunakan tuturan bahasa Sunda menyampaikan materi ceramahnya, tetapi kemudian beralih ke bahasa Arab terutama ketika menyampaikan sebuah konsep penting yang perlu diketahui jamaah yang mendegarkan, beliau mencoba meyakinkan para jamaah akan konsep sebuah amanah yang diberikan oleh Allah kepada manusia, dalam penggalan ceramah ini K.H Jamaludin 
menceritakan bahwasan masih bayak manusia yang dzalim terhadap Allah yaitu meninggalkan perintah Allah, Hukum Allah dan ajaran-ajaran agama Allah yang dibawa oleh nabi-Nya. Fungsi Alih Kode dalam ceramah diatas adalah menegaskan Hukum Allah.

/shalat sunnah $(B A) \rightarrow$ komo tara tinggaleun maca $(B S) \rightarrow$ shalawatna $(B A) \rightarrow$ rada beki istighfarna $(B A) \rightarrow$ daekan (BS)./

Terjemah : Shalat sunnah tidak suka tertinggal suka baca shalawat dan suka beristighfar.

Data (No. 2.14 ) Penggalan ceramah di atas menyampaikan peralihan kode dari bahasa Arab ke bahasa Sunda. Awalnya, K.H Jamaludin menggunakan tuturan bahasa Arab menyampaikan materi ceramahnya, tetapi kemudian beralih ke bahasa Sunda dan kembali menggunakan bahasa Arab terutama ketika menyampaikan sebuah konsep penting yang perlu diketahui jamaah yang mendegarkan, beliau mencoba meyakinkan para jamaah akan konsep sebuah amanah yang diberikan oleh Allah kepada manusia, dalam penggalan ceramah ini K.H Jamaludin menjelaskan pahala bagi orang yang rajin beribadah. Fungsi Alih Kode dalam kontek disini K.H Jamaludin mencoba menegaskan sebuah konsep Hukum.

/coba cek gusti (BS) $\rightarrow$ Allah (BA) $\rightarrow$ tanya eta kakasih aing mana (BS) $\rightarrow$ amanat-amanat $(\mathrm{BA}) \rightarrow$ ti aing anu dibikeun $\mathrm{ka}(\mathrm{BS}) \rightarrow$ umat-umatna (BA) $\rightarrow$ coba dilaksanaken tah harente? (BS)/

Terjemah BI : Allah berkata coba tanya kepada kekasih-Ku amanat-amanat dari-Ku yang diberikan kepada umatnya apakah dilaksankan atau tidak?.
Data (No. 2.16) Penggalan ceramah di atas menyampaikan peralihan kode dari bahasa Sunda. Ke bahasa Arab Awalnya, K.H Jamaludin menggunakan tuturan bahasa Sunda menyampaikan materi ceramahnya, tetapi kemudian beralih ke bahasa Arab terutama ketika menyampaikan sebuah konsep yang yaitu sebuah amanah yang Allah telah sampaikan kepada Nabi Muhamad apakah telah disampaikan kepada umatnya, dalam penggalan ceramah diatas K.H Jamaludin mejelaskan sebuah proses amanah dari Allah sampai kepada manusia, dan Amanah ini harus dijalankan oleh manusia. Fungsi Alih kode dalam penggalan ceramah di atas adalah sebuah penegasan hukum dalam Agama islam.

/Angkat $(B S) \rightarrow$ wasilah syafaat $(B A)$ $\rightarrow$ anjen $(B S) \rightarrow$ diizinan $(B A) \rightarrow k u$ aing $(B S), \rightarrow$ alhamdulillah $(B A) /$

Terjemah BI : angkat dengan cara syafaat dari-ku kamu diizinkan oleh-Ku, alhamdulillah(syukur).

Data (No. 2.18 ) Penggalan ceramah di atas menyampaikan peralihan kode dari bahasa Sunda. Ke bahasa Arab Awalnya, K.H Jamaludin menggunakan tuturan bahasa Sunda menyampaikan materi ceramahnya, tetapi kemudian beralih ke bahasa Arab terutama ketika menyampaikan sebuah konsep yang yaitu sebuah amanah yang Allah telah sampaikan kepada Nabi Muhamad apakah telah disampaikan kepada umatnya, dalam penggalan ceramah diatas K.H Jamaludin mejelaskan sebuah proses amanah dari Allah sampai kepada manusia, dan Amanah ini harus dijalankan oleh manusia. Fungsi Alih kode. 
Komunikatif Dalam Menjelaskan

Iniatna $(B A) \rightarrow$ endahkeun heula oge ka para pamuda nu rek (BS) kararawin $(B A) \rightarrow$ ulah asal ngasaan doang $(B S)$ $\rightarrow$

$$
\text { / ان الله لا يحب الذواقين والذواقات }
$$

Terjemah BI : Memiliki Niat baik terlebih dahulu kepada para pemuda yang ingin menikah jangan asal hanya ingin merasakan saja.

Data (No. 1.6 ) Penggalan percakapan di atas menyampaikan peralihan kode dari bahasa Arab ke bahasa Sunda kemudian ke bahasa Arab. Awalnya, K.H Jamaludin menggunakan tuturan bahasa Arab saat menyampaikan materi ceramahnya, tetapi kemudian beralih ke bahasa Sunda dan Arab terutama ketika menyampaikan sebuah konsep penting yang perlu diketahui jamaah yaitu sebuah hukum dalam melakukan kehidupan dan berhubungan antar lawan jenis harus ada status yang sah yaitu sebuah pernikahan. K.H Jamaludin sangat komunikatif agar pesan hukum tersampaikan kepada jamaah hususnya kepada para pemuda dan pemudi.

/pileum mantak $(B S) \rightarrow$ perzinahan $(B A) \rightarrow$ dimana-mana $(B I) /$

Terjemah BI : Film yang menjadikan perzinahan imana-mana.

Data (No. 1.12 ) Penggalan percakapan di atas menyampaikan peralihan kode dari bahasa Sunda kemudian ke bahasa Arab. Awalnya, K.H Jamaludin menggunakan tuturan bahasa Sunda saat menyampaikan materi ceramahnya, tetapi kemudian beralih ke bahasa Arab terutama ketika menyampaikan sebuah konsep penting yang perlu diketahui jamaah yaitu sebuah konsep hukum dalam Agama yaitu akibat sebuah perbuatan zinah yang dapat merusak. K.H Jamaludin sangat komunikatif agar pesan hukum dan akhlak tersampaikan kepada jamaah hususnya kepada para jamaah.

/Barang (BS) $\rightarrow$ haram wasilah pertikahan $(B A) \rightarrow$ jadi $(B I) \rightarrow$ halal alhamdulillah (BA)/

Terjemah BI : Sesuatu yang haram dengan wasilah pernikahan menjadi halal alhamdulillah.

Data (No. 1.19 ) Penggalan percakapan di atas menyampaikan peralihan kode dari bahasa Sunda kemudian ke bahasa Arab. Awalnya, K.H Jamaludin menggunakan tuturan bahasa Sunda saat menyampaikan materi ceramahnya, tetapi kemudian beralih ke bahasa Arab terutama ketika menyampaikan sebuah konsep penting yang perlu diketahui jamaah yaitu sebuah konsep hukum dalam Agama. K.H Jamaludin sangat komunikatif agar pesan hukum tersampaikan kepada jamaah hususnya kepada para jamaah.

/lamun ie sawah aing ditungguan $k u$ dia, bari lauk emasna ku dia (BS) $\rightarrow$ disalametkeun $(B A) \rightarrow$ bisi sero $(B S) /$

Terjemah BI : Apabila sawah saya dijaga oleh kamu juga diselamatkan oleh kamu karena ada hama (sero) lasun.

Data (No. 2.5 ) Penggalan percakapan di atas menyampaikan peralihan kode dari bahasa Sunda kemudian ke bahasa Arab. Awalnya, K.H Jamaludin menggunakan tuturan bahasa Sunda saat menyampaikan materi ceramahnya, tetapi kemudian beralih ke bahasa Arab 
terutama ketika menyampaikan sebuah konsep penting yang perlu diketahui jamaah yaitu sebuah konsep hukum amanah, dalam cerita ini ketika manusia diberi amanah akankan dia berkhianat atau dapat dipercaya hikmahya.

/pancek (BS) $\rightarrow$ allah $(\mathrm{BA}) \rightarrow$ dina $(\mathrm{BS})$ $\rightarrow$ qur'an (BA):

$$
\text { أن الأرض يرثها عبادي الصالحونج (BA) }
$$

saenya-enyana ie $(B S) \rightarrow$ bumi $(B I) \rightarrow$ diwariskeun $(B A) \rightarrow k u(B S) \rightarrow$ Allah $(B A) \rightarrow$ diciptakeun $k u(B S) \rightarrow$ Allah swt $(B A) \rightarrow$ jeng jalemaa anu sok daek $(B S) \rightarrow$ ngamal shaleh $(B A) /$

Terjemah BI : Allah dalam AlQuran berkata : sesungguhnya Allah mewariskan bumi kepada orang yang melakukan amal shaleh. sesungguhmya bumi diwariskan dan diciptakan oleh Allah kepada manusia yang suka beramal shaleh.

Data (No. 2.6 ) Penggalan percakapan di atas menyampaikan peralihan kode dari bahasa Sunda kemudian ke bahasa Arab. Awalnya, K.H Jamaludin menggunakan tuturan bahasa Sunda saat menyampaikan materi ceramahnya, tetapi kemudian beralih ke bahasa Arab terutama ketika menyampaikan sebuah konsep penting yang perlu diketahui jamaah yaitu sebuah konsep hukum dalam Agama yaitu sebuah amanat yang diwriskan oleh Allah kepada manusia. K.H Jamaludin sangat komunikatif agar pesan hukum tersampaikan kepada jamaah hususnya kepada para jamaah.

/Betul apa betul? (BI) $\rightarrow$

$$
\text { أن الأرض يرثها عبادي الصالحونج (BA) }
$$

saenya-enyana ie $(B S) \rightarrow$ bumi $(B I) \rightarrow$ diwariskeun $(B A) \rightarrow k u(B S) \rightarrow$ Allah $(B A) \rightarrow$ jeung jalema nu sok daek $(B S)$ $\rightarrow$ Agama (BI) $\rightarrow$ shaleh (BA) $\rightarrow$ hirup di $(B S) \rightarrow$ alam dunia $(B A)$ /

Terjemah : betul apa betul? “ sesungguhnya bumi diwariskan kepada orang yang beramal shaleh" , sesungguhnya bumi diwariskan kepada orang yang beramal shaleh yang hidup di alam dunia.

Data (No. 2.11 ) Penggalan percakapan di atas menyampaikan peralihan kode dari bahasa Indonesia ke bahasa Arab. Awalnya, K.H Jamaludin menggunakan tuturan bahasa Indonesia saat menyampaikan materi ceramahnya, tetapi kemudian beralih ke bahasa Arab terutama ketika menyampaikan sebuah konsep penting yang perlu diketahui jamaah yaitu sebuah konsep hukum dalam Agama yaitu sebuah amanat yang diwariskan oleh Allah kepada manusia. K.H Jamaludin sangat komunikatif agar pesan hukum tersampaikan kepada jamaah hususnya kepada para jamaah.

/hadirin $(B A) \rightarrow$ sadaya $(B S) \rightarrow$ shalat $(B A) \rightarrow$ kadang-kadang $(B S) \rightarrow$ hakekatna $(B A) \rightarrow$ ngadzaliman $(B A)$ $\rightarrow$ awak sarangan (BS/

Terjemah BI : Hadirin semua shalat kadang-kadang hakikatnya mendzalimi diri sendiri.

Data (No. 2.13 ) Penggalan percakapan di atas menyampaikan peralihan kode dari bahasa bahasa Arab ke bahasa Sunda. Awalnya, K.H Jamaludin menggunakan tuturan bahasa Arab saat menyampaikan materi ceramahnya, tetapi kemudian beralih ke bahasa Sunda dan krmbali mrnggunakan bahasa Arab terutama ketika menyampaikan sebuah konsep penting yang perlu 
diketahui jamaah yaitu sebuah konsep hukum dalam Agama yaitu sebuah amanat yang diwriskan oleh Allah kepada manusia yaitu sebuah amalan ibadah kepada Allah. K.H Jamaludin sangat komunikatif agar pesan hukum tersampaikan kepada jamaah hususnya kepada para jamaah dan mengingat lebih kuat lagi kepada Allah dalam beribadah.

anak ibu $(B I) \rightarrow k u(B S) \rightarrow i b u(B I) \rightarrow$ diparaban $(B S) \rightarrow$ dzahiriyahna $(B A) /$

Terjemah BI : Anak ibu oleh ibu diberi makan secara dzhairnya.

Data (No.2.15) Penggalan percakapan di atas menyampaikan peralihan kode dari bahasa Sunda kemudian ke bahasa Arab. Awalnya, K.H Jamaludin menggunakan tuturan bahasa Sunda saat menyampaikan materi ceramahnya, tetapi kemudian beralih ke bahasa Arab terutama ketika menyampaikan sebuah konsep penting yang perlu diketahui amaah yaitu sebuah amanah dalam memberikan nafkah kepada anak, fugsi Alih Kode disini adalah sebuah peringatan akan hukum Allah untuk menjalankan Amanah.

/ka urang Rangkas ka urang Pandeglang waduh nya (BA) $\rightarrow$ umat (BA) $\rightarrow$ kaula mah ngaredul mana laletik (BS) $\rightarrow$ elmuna (BA) $\rightarrow$ aripis (BS) $\rightarrow$ kaimananana (BA) $\rightarrow$ laletik awakna tapi galede hutangna (BS)/

Terjemah : Kepada orang rangkas kepada orang Pandeglang, waduh umat$\mathrm{Ku}$ malas ilmunya tipis, ke imananya sedikit, badanya kecil tapi hutangnya besar.

Data (No. 2.17) Penggalan percakapan di atas menyampaikan peralihan kode dari bahasa Sunda kemudian ke bahasa Arab. Awalnya, K.H Jamaludin menggunakan tuturan bahasa Sunda saat menyampaikan materi ceramahnya, tetapi kemudian beralih ke bahasa Arab terutama ketika menyampaikan sebuah konsep penting yang perlu diketahui jamaah yaitu sebuah kritik terhadap amalan ibadah kita kepada Allah, K.H Jamaludin mencba mengingatkan dengan komunikatif agar mudah diterima oleh para jamaah.

$/ k u m a h a(B S) \rightarrow$ amalna $(B A) \rightarrow$ aya nu saratus tahun, aya anu $(B S) \rightarrow$ dua (BI) $\rightarrow$ rebu $(B S) \rightarrow$ tahun $(B I), \rightarrow$ aya anu $(B S) \rightarrow$ dua ratus tahun $(B I), \rightarrow$ aya anu sapuluh $(B S) \rightarrow$ tahun $(B I) /$

Terjemah BI : Bagaimana amalanya ada yang sratus tahun, dua ribu tahun, ada yang dua ratus tahun, ada yang sepuluh tahun.

Data (No. 2.19 ) Penggalan percakapan di atas menyampaikan peralihan kode dari bahasa Sunda ke bahasa Arab. Awalnya, K.H Jamaludin menggunakan tuturan bahasa Sunda saat menyampaikan materi ceramahnya, tetapi kemudian beralih ke bahasa Arab terutama ketika menyampaikan sebuah konsep penting yang perlu diketahui jamaah yaitu sebuah peringatan dalam melakukan ibadah, maksudnya debuah kritik dari K.H Jamaludin kepada para jamaah dalam menjalankan ketaatan ibadah kepada Allah. Fugsi Alih Kode dalam ceramah di atas adalah sebuah perigatan akan hukum Allah.

Imodalna dua ie nu rek $(B S) \rightarrow$ dibahas $(B I) \rightarrow k u$ simkuring sugan aya $(B S) \rightarrow$ manfaatna $(B A) /$

Terjemah : Modalnya Dua Ini Yang Akan Dibahas Oleh Saya Semoga Ada Manfaatnya.

Data (No. 2.20) Penggalan percakapan di 
atas menyampaikan peralihan kode dari bahasa Sunda ke bahasa Arab. Awalnya, K.H Jamaludin menggunakan tuturan bahasa Sunda saat menyampaikan materi ceramahnya, tetapi kemudian beralih ke bahasa Arab terutama ketika menyampaikan sebuah konsep penting yang perlu diketahui jamaah yaitu manfaat dalam kita beribadah taat kepada Allah yaitu hikmah dan pahala ketika kita taat dan rajin dalam beribadah kepada Allah.

lie model Rohman man kumaneh nyupir waduuh urang mah belang-bentong $(B S) \rightarrow$ shalatna $(B A) /$

Terjemah BI : Ini seperti Rohman,Man kamu nyupir waduh menurut saya shalatnya masih bolong-bolong.

Data (No. 2.21) Penggalan percakapan di atas menyampaikan peralihan kode dari bahasa Sunda ke bahasa Arab. Awalnya, K.H Jamaludin menggunakan tuturan bahasa Sunda saat menyampaikan materi ceramahnya, tetapi kemudian beralih ke bahasa Arab terutama ketika menyampaikan sebuah konsep penting yang perlu diketahui jamaah yaitu peringatan tentang sebuah hukum dalam beribadah yaitu ketika lalai dalam Shalat, dalam penggalan ceramah diatas salah satu jamaah menjadi contoh. Fungsi Alih Kode untul menegaskum menerangkan hukum dalam beribadah.

/Naon $(B S) \rightarrow$ sebabna?, rasulullahna $(B A) \rightarrow$ eh sieuneun $k a(B S) \rightarrow$ Allah $(B A), \rightarrow$ maka seluruh $(B S) \rightarrow$ makhluk $(B A) \rightarrow$ bakal dibere tunduk ka manusia $(B S) /$

Terjemah BI : Apa Sebabnya?, Karena Rasulullahpun Tunduk Kepada Allah, Maka Seluruh makhlukpunAkan Tunduk Kepada Manusia (Nabi Muhammad).
Data (No. 2.23) Penggalan percakapan di atas menyampaikan peralihan kode dari bahasa Sunda ke bahasa Arab. Awalnya, K.H Jamaludin menggunakan tuturan bahasa Sunda saat menyampaikan materi ceramahnya, tetapi kemudian beralih ke bahasa Arab terutama ketika menyampaikan sebuah konsep penting yang perlu diketahui jamaah yaitu peringatan tentang sebuah hukum bagaimana hikmah dari amanah apabila manusia bias melaksanakanya, dalam ceramah diatas fungsi Alih Kode sebagai penguat dalam penjelasan ceramah tersebut.

latuh cenah mending $(B S) \rightarrow$ beribadah (BA)/.

Terjemah BI : Katanya mending beribadah.

Data (No.2.24) Penggalan percakapan di atas menyampaikan peralihan kode dari bahasa Sunda ke bahasa Arab. Awalnya, K.H Jamaludin menggunakan tuturan bahasa Sunda saat menyampaikan materi ceramahnya, tetapi kemudian beralih ke bahasa Arab terutama ketika menyampaikan sebuah konsep penting yang perlu diketahui jamaah karena ini menyangkut amanat yang harus dilaksanakan oleh manusi. Fungsi Alih Kode berguna untuk memperkuat dalam pejelasan amanat dalam ceramah tersebut.

Inah dia mah aih kitu mah mending (BS) $\rightarrow$ dimiskinkeun $(B A) \rightarrow$ bae ku Aing $(B S) /$

Terjemah BI : Nah kalau seperti itu mending dimiskinkan saja oleh-Ku.

Data(No.2.25) Penggalan percakapan di atas menyampaikan peralihan kode dari bahasa Sunda ke bahasa Arab. Awalnya, K.H Jamaludin menggunakan tuturan 
bahasa Sunda saat menyampaikan materi ceramahnya, tetapi kemudian beralih ke bahasa Arab terutama ketika menyampaikan sebuah konsep penting yang perlu diketahui jamaah, penggalan percakapa diatas adalah perkataan Allah bagi manusia yang tidak taat, fugsi Alih Kode dalam ceramah tersebut lebih komunikatif agar para jamaah dapat memahaminya.

/dititah geh ngala $(B S) \rightarrow$ elmuna $(B A)$ $\rightarrow$ jadi kiayi $(B S) \rightarrow$ fadol $(B A) \rightarrow t i$ $(B S) \rightarrow$ Allah $(B A) /$

Terjemah BI : Diperintahkan juga mengambil ilmunya kalau jadi kiyai izin dari Allah.

Data (No. 2.27 ) Penggalan ceramah di atas menyampaikan peralihan kode dari bahasa Sunda ke bahasa Arab. Awalnya, K.H Jamaludin menggunakan tuturan bahasa Sunda saat menyampaikan materi ceramahnya, tetapi kemudian beralih ke bahasa Arab terutama ketika menyampaikan sebuah konsep penting yang perlu diketahui jamaah yaitu sebuah konsep keagamaan apabila para jamaah menginginkan sebuah sesuatu terus mendapat berkah dan kebaikan, K.H Jamaludin mengajak untuk menambah pengetahuan.

Membangkitkan Simpatik

/ceng $(B S) \rightarrow$ nyalatkeun $(B A) \rightarrow$ ceng $(B S) \rightarrow$ nyalatkeun $(B A) \rightarrow$ kabeh $(B S)$ $\rightarrow$.. nyalatkeun.. nyalatkeun..(BA) $\rightarrow$ kuat $(B I) \rightarrow$ eor kabeh $(B S) \rightarrow$ santri $(B I) \rightarrow$ can $(B S) \rightarrow$ shalat subuh $(B A) \rightarrow$ geh digageak $(B S) \rightarrow$ langsung $(B I) /$

Terjemah BI : nak menyolatkan nak menyolatkan...semua menyolatkan.. menyolatkan...

ramai semua santri belum shalat subuh juga diburu-buru langsung.

Data (No. 1.16 ) Penggalan percakapan di atas menyampaikan peralihan kode dari bahasa Sunda kemudian ke bahasa Arab. Awalnya, K.H Jamaludin menggunakan tuturan bahasa Sunda saat menyampaikan materi ceramahnya, tetapi kemudian beralih ke bahasa Arab terutama ketika menyampaikan sebuah konsep penting yang perlu diketahui jamaah yaitu sebuah konsep hukum dalam Agama yaitu sebuah cerita di pesantren beliau ketika beliau memerintahkan santri meyalatkan, santri lagsung semangat karena ini perintah seorang guru dan juga para santri tahu bahwasanya nanti akan mendapatkan imbalan berupa uang ketika menyalatkan. K.H Jamaludin dalam cerita ini mencoba meyampaikan pesan sosial.

/kiayina ker ngabangun $(B S) \rightarrow$ majlis (BA), $\rightarrow$ barang dibere amplop tea coba ceng kumpulken nu $(B S) \rightarrow$ nyalatkeun $(B A) \rightarrow$ tadi $(B I) \rightarrow$ aya meureun 70 an mah kie ceng ie pan $(B S) \rightarrow$ majlis $(B A)$ $\rightarrow$ ker dibangun pan $(B S) \rightarrow$ majlis $(B A) \rightarrow$ urang ie jeng ngaji $(B S) /$

Terjemah BI : Kiyainya sedang membangun Majlis, setelah dikasih amplop, coba nak Maaf saja, amplop yang tadi akan dipakai untuk membangun Majlis kita, bagaimana setuju?. dikumpulkan. Yang menyolatkan mungkin ada 70 an, begini nak Majlis sedang dibangun karena Majlis kita ini untuk mengaji.

Data (No. 1.17 ) Penggalan percakapan di atas menyampaikan peralihan kode dari bahasa Sunda kemudian ke bahasa Arab. Awalnya, K.H Jamaludin menggunakan tuturan bahasa Sunda saat menyampaikan materi ceramahnya, 
tetapi kemudian beralih ke bahasa Arab terutama ketika menyampaikan sebuah konsep penting yang perlu diketahui jamaah yaitu sebuah konsep hukum dalam Agama yaitu sebuah cerita di pesantren beliau ketika beliau memerintahkan santri meyalatkan, santri lagsung semangat karena ini perintah seorang guru dan juga para santri tahu bahwasanya nanti akan mendapatkan imbalan berupa uang ketika menyalatkan dan uang diguakan untuk pembangunan majlis. K.H Jamaludin dalam cerita ini mencoba meyampaikan pesan sosial.

/meunang tilu poe aya nu paeh dei cek kiyaina ceng $(B S) \rightarrow$ nyalatkeun $(B A) ! !$ $\rightarrow$, eta santri nu nyaletuk endek carek kamari dei tah moal?(BS)/

Terjemah BI : Setelah tiga hari ada yang meninggal lagi, kata kiyai : nak menshalatkan, ada santri yang nyeletuk, apa akan sepert yang kemarin?.

Data (No. 1.18 ) Penggalan percakapan di atas menyampaikan peralihan kode dari bahasa Sunda kemudian ke bahasa Arab. Awalnya, K.H Jamaludin menggunakan tuturan bahasa Sunda saat menyampaikan materi ceramahnya, tetapi kemudian beralih ke bahasa Arab terutama ketika menyampaikan sebuah konsep penting yang perlu diketahui jamaah yaitu sebuah konsep hukum dalam Agama yaitu sebuah cerita di pesantren beliau ketika beliau memerintahkan santri meyalatkan, santri langsung semangat akan tetapi ada hal kritis yang disampaika santri karena ini perintah seorang guru dan juga para santri tahu bahwasanya nanti akan mendapatkan imbalan berupa uang ketika menyalatkan dan uang diguakan untuk pembangunan majlis. K.H Jamaludin dalam cerita ini mencoba meyampaikan pesan sosial dan akhlak.

\section{Kesimpulan}

Melihat dari analisis dan pembahasan hasil-hasil penelitian ini, maka dapat ditarik beberapa kesimpulan sebagai berikut.

Variasi bahasa CKBSP memiliki ciri khas hal ini dilihat dari interaksi verbal dalam situasi kontak bahasa. Untuk itu variasi bahasa CKBSP ditemukan satu konsistensi berbahasa Sunda. Konsistensi ini merupakan kontribusi konsep teori variasi bahasa setelahnya yang menyebut memiliki satu aspek yaitu alih kode, secara empiris konsistensi berbahasa Sunda dalam ceramah keagamaan Bahasa Sunda K.H Jamaludin dapat terefleksi dari dua konteks komunikasi Verbal, yaitu saat memberikan penjelasan mengenai materi dalam konsep bahasa Arab dan berinteraksi dengan jamaah dalam ceramahnya.

Alih Kode pada CKBSP di Pandeglang Banten, dapat dibedakan menjadi enam bentuk yaitu : yag terdiri dari Alih Kode intern (1) Alih Kode dari bahasa Sunda ke bahasa Indonesia, (2) dari bahsa Indonesia ke bahasa Sunda, dan (3) ekstern terdiri dari bahasa Sunda ke bahasa Arab, (4) dari bahasa Indonesia ke bahasa Arab, (5) dari bahasa Arab ke bahasa Sunda, (6) dari bahasa Arab ke bahasa Indonesia.

Adapun penulis berhasil menemukan 57 kasus bentuk kata pinjaman yang menggunakan sisipan bahasa Sunda dalam ceramah CKBSP di Pandeglang Banten, 57 kasus tersebut terjadi pada 366 penggalan kalimat yang terdapat peristiwa Alih Kode dalam CKBSP, 57 kasus ini kemudian diklasifikasikan berdasarkan bentuknya dalam imbuhan Sunda (1) Afiks berjumlah 4 kalimat, 
(2) Sufiks berjumlah 27 kalimat, (3) Konfiks berjumlah 21 kalimat, (4) Infiks berjumlah 3 kalimat dan kalimat yang memiliki bentuk Infiks dan sufiks didalamnya berjumlah 2 kalimat.

Ditinjau dari khazanah bahasa dalam CKBSP kita bisa melihat pilihan bahasa yang digunakan oleh penceramah ditentukan oleh tiga faktor, yaitu : situasi, kejiwaan dan politik. Faktor situasi bias dilihat dari Para jamaah yang memiliki ragam suku sangat jelas peceramah menggunakan alih kode karena pertimbangan mitra tuturnya yaitu para jamaah. Dalam faktor kejiwaan bisa kita lihat dengan lima ciri faktor tersebut yang menjadi faktor peralihan kode yang diamati oleh peneliti yaitu : 1) suka tidak suka, 2) pemenuhan kebutuhan pribadi, 3) perasaan sebagai teman sebaya, 4) kebiasaan, 5) bakat. Kemudian faktor politik bahasa, pada ceramah keagamaan berbahasa Sunda di Pandeglang yang dilakukan oleh K.H Jamaludin dengan baik menggunakan ketiga yang pertama dalam pelafalan, kosa kata dan tata bahasa, aspek yang kedua adalah statusplaning yaitu kedudukan bahasa Sunda dalam bahasa Arab dan Indonesia.

Ketiga aspek di atas digunakan sebagai identitas sosial beliau agar para jamaah bisa menilai bahwasanya beliau adalah seorang ulama yang kuat akan segala keilmuan berbahasa, agama dan sosial, karena ketiga aspek tadi, menunjang seluruh materi ceramah yang dikemukan, agar para jamaah faham terhadap materi yang disampaiakan. Temuan ini sekaligus berfungsi sebagai indikator pilihan bahasa dalam CKBSP yang membedakan penelitian ini dengan penelitian alih kode lainya.

Kemudian dari Fungsi, fungsi Alih
Kode yang ditemukan dalam CKBSP di Pandeglang Banten adalah sebagai berikut: (1) lebih Argumentatif meyakinkan mitra tutur, berjumlah 7 kalimat, (2) lebih komunikatif dalam menjelaskan berjumlah 21 kalimat, (3) lebihpersuasifataumenyuruh, berjumlah 16 kalimat (4) lebih membangkitkan simpatik berjumlah 3 kalimat.

Ceramah-ceramah K.H Jamaludin adalah ceramah keagamaan yang sangat familiar di Banten hususnya warga Pandeglang. Sejauh ini penulis belum menemukan peneliti-peneliti yang telah menggunakan Ceramah-ceramah ini sebagai korpus utama dalam penulisan karya ilmiah baik itu skripsi maupun tesis dan karya ilmiah lainnya. Penulis merupakan peneliti pertama yang menggunakan ceramah ini dalam karya linguistik apalagi dalam jurusan bahasa dan sastra Arab oleh karena itu sangat diharapkan akan ada peneliti-peneliti selanjutnya yang meneruskan objek kajian dari ceramah keagamaan K.H Jamaludin Pandeglang ini dalam aspek yang berbeda, mengingat isu-isu yang terdapat dalam ceramah ini masih dikatakan up to date. Dan penceramah pun masih aktif berceramah hingga saat ini tentunya sangat membutuhkan penggalian lebih lanjut.

Berdasarkan kesimpulan hasil penelitian alih kode dalam ceramah keagamaan bahasa Sunda K.H Jamaludin, kita dapat melihat kemampuan manusia dalam berbahasa sangatlah beragam, terlebih bagi kita yang hidup di era global saat ini harus peka dalam mengamati bahasa yang berkembang di lingkungan kita, adanya keilmuan yang membahas kebahasaan atau linguistik, hal ini yang akan menjadikan manusia tersebut berlaku kritis, cerdas dan peka terhadap gejala dan keberagaman bahasa yang 
ada di sekitarnya, oleh karena itu, kajian sosiolinguistik alih kode dalam ceramah keagamaan K.H Jamaludin PandeglangBanten ini perlu mendapatkan perhatian dan pengembangan lebih lanjut terutama bagi para peneliti linguistik.

\section{Daftar Pustaka}

Sumber buku

A. Chaedar Alwasilah. (1997). Politik bahasa dan pendidikan (Vol. 1). PT. Remaja Rosdakarya.

Abdul Chair. (2002). Psikolinguistik: Kajian Teoritik. Jakarta: PT. Rineka Cipta.

Abdul Chair, \& Leonie Agustina. (2010). Sosiolinguistik Perkenalan Awal (Revisi). Jakarta: PT. Rineka Cipta.

Amalia Rizqi Khoiriyah. (2012). Campur kode dan aliih kode dalam komik Nodame Cantabile, 3.

Deddy Mulyana, \& Jalaluddin Rakhmat. (2006). Komunikasi antarbudaya: panduan berkomunikasi dengan orangorang berbeda budaya (Revisi). Jakarta: Remaja Rosdakarya.

M.S, Mahsun. (2007). Metode Penelitian Bahasa: Tahapan Strategi, Metode, dan Tekniknya (1 ed., Vol. 1). Jakarta: PT. Raja Grafindo Persada.

M.S, Mahsun. (2012). Metode penelitian bahasa tahapan strategi, metode, dan tekniknya (Revisi, Vol. 6). Jakarta: Rajawali Pers.

Muhammad. (2011). Metode Penelitian
Bahasa (1 ed.). Yogyakarta: ArRuzz Media.

Sudarno. (1992). Kata serapann dari bahasa Arab (Revisi, Vol. 1-2). Jakarta: Arikha Media Cipta.

Sukron Kamil. (2013). Pemikiran Politik Islam Tematik: (Agama dan Negara, Demokrasi, Civil Society, Syariah dan HAM, Foundamentalisme, dan Anti korupsi) (Vol. 1-1). Jakarta: Kencana, Prenada Media Group.

Wafi, Ali Abdul Wahid. (1971). AlLughah wa Al-Mujtama. Kairo: ahdhah Mishr. 